This PDF is a selection from a published volume from the National Bureau of Economic Research

Volume Title: Financial Markets Volatility and Performance in Emerging Markets

Volume Author/Editor: Sebastian Edwards and Márcio G.

P. Garcia, editors

Volume Publisher: University of Chicago Press

Volume ISBN: 0-226-18495-1

Volume URL: http://www.nber.org/books/edwa05-1

Conference Date: December 1-3, 2005

Publication Date: March 2008

Title: Sudden Stops and IMF-Supported Programs

Author: Barry Eichengreen, Poonam Gupta, Ashoka Mody

URL: http://www.nber.org/chapters/c4779 


\title{
Sudden Stops and \\ IMF-Supported Programs
}

\author{
Barry Eichengreen, Poonam Gupta, and Ashoka Mody
}

\subsection{Introduction}

The debate over the role of the International Monetary Fund (IMF) in a world of capital mobility shows no signs of dying down. There is broad awareness that the single factor that most distinguishes our current economic and financial environment from that of the preceding period is high capital mobility. There is also a widely held view that while exposure to international capital markets promises benefits, those benefits come packaged with risks. But there is no consensus on what the IMF should do about it. Should the Fund reduce its role as emergency lender on the grounds that countries enjoy increasing access to markets as an alternative source of finance? Or should it expand its role as relations with international financial markets expose countries to abrupt and potentially costly reversals in the direction of capital flows? Are existing IMF facilities adequate for these needs? Or is there a case for a new facility capable of disbursing large amounts of financial assistance quickly, perhaps on the basis of prequalification, to countries experiencing sudden shifts in the direction of capital flows?

Barry Eichengreen is the George C. Pardee and Helen N. Pardee Professor of Economics and Political Science at the University of California, Berkeley, and a research associate of the National Bureau of Economic Research. Poonam Gupta is a professor of economics at the Delhi School of Economics. Ashoka Mody is an assistant director in the European Department of the International Monetary Fund.

We thank Mohammed Dairi, Matthew Fisher, Marianne Schulze-Ghattas, Jeromin Zettelmeyer, and other colleagues at the International Monetary Fund (IMF) for comments and Sudarat Ananchotikul and Anna Unigovskaya for research assistance. The views expressed in this paper are those of the authors and do not necessarily represent those of the IMF or IMF policy.

1. Two recent reviews of the debate that elaborate these points are Ostry and Zettelmeyer (2005) and Truman (2005). 
More evidence may help to answer these questions. There exists substantial empirical literature on both shifts in the direction of capital flows (known by the moniker "sudden stops") and the effects of IMF-supported programs (see tables 7.1 and 7.2). Empirical analyses focus on the impact of policies and characteristics like a country's exchange rate regime, financial openness, and dependence on international trade on the incidence, magnitude, and effects of sudden stops. Analyses of IMF-supported programs examine the behavior of inflation, output, fiscal effort, and, most relevant to the questions at hand, the balance of payments, compared to a control group of country-year cases with no program in place. But, to our knowledge, there exists no study focusing on the impact of such programs on the incidence, severity, and effects of sudden stops.

In this paper we take a first stab at developing such evidence. Our results suggest that IMF-supported programs and IMF credits reduce the likelihood of sudden stops. There is some evidence that this stabilizing effect is stronger for countries with strong fundamentals. This can be interpreted in terms of the literature on global capital account shocks and the stabilizing effect of liquidity insurance. Even countries with strong policies may experience a sudden curtailment of capital inflows and a shift to outflows if investors suspect that other investors for whatever reason are primed to take their money out of the country. Emergency financial assistance can then reassure individual investors of the country's continued ability to finance its international transactions and reduce their incentive to liquidate their positions. Emergency lending by the IMF can ensure the continued provision of private finance in much the way that lender-of-last-resort intervention by a central bank can limit the scope for bank runs. But if country fundamentals are weak, IMF financial assistance may only come in the front door and go out the back door with no impact on the incidence of the sudden stop.

There are reasons to treat these results with caution. There is the difficulty of measuring both IMF-supported programs and sudden stops. There is the challenge of identifying the impact of the former on the latter-of addressing potential endogeneity. Our solutions to these problems are imperfect. Our analysis also leaves open a variety of issues such as appropriate modalities for lending to countries in this position, the feasibility of identifying qualifying countries in the relevant time frame, and moral hazard. While these are not our topics in this paper, this does not mean they are unimportant. Still, we believe that our results are the first evidence of the insurance properties of IMF-supported programs.

\subsection{Sudden Stops and Multilateral Insurance}

The fact that sudden stops cluster in time is taken as suggesting that they have more to do with the behavior of global financial markets than with country policies, which some commentators take to imply that their 


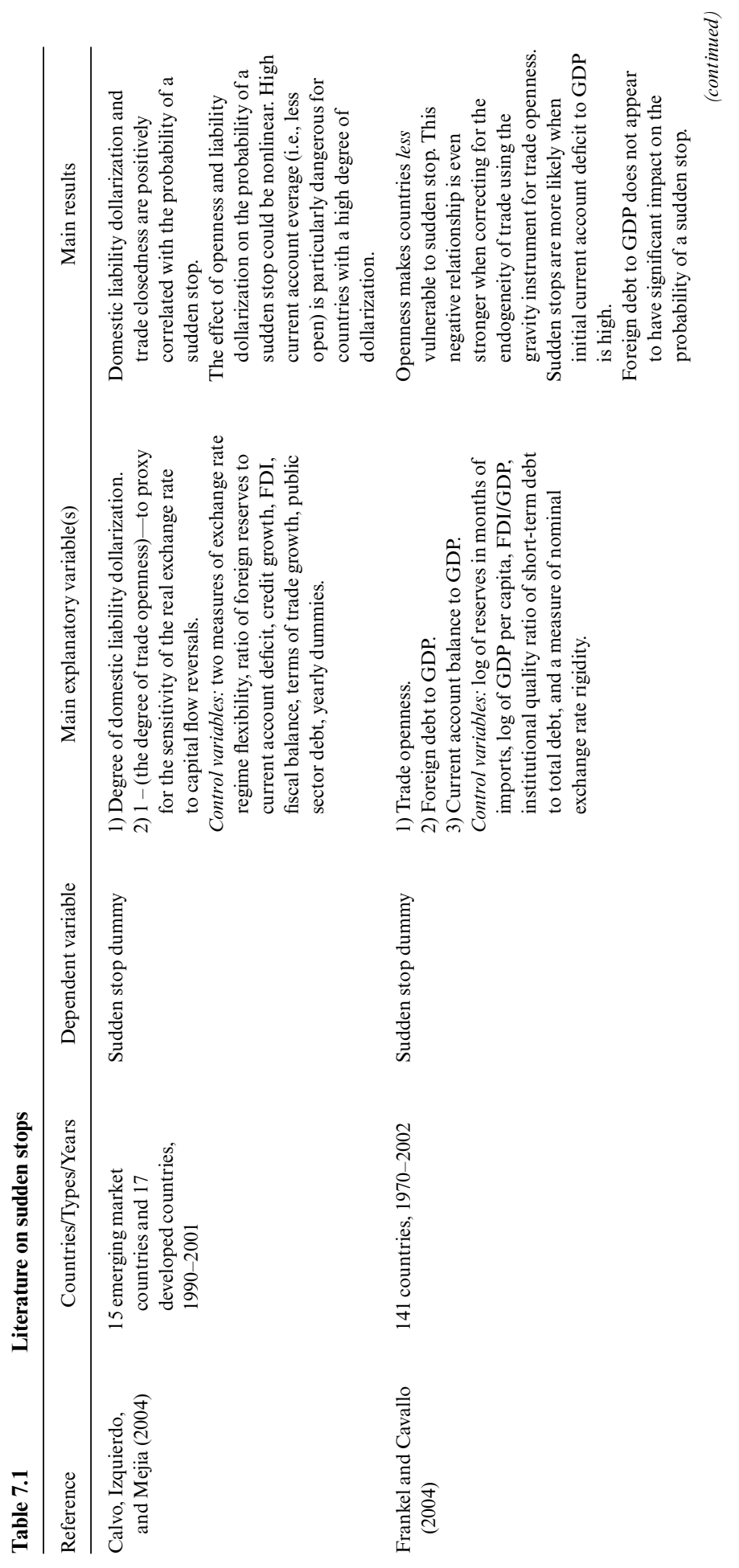




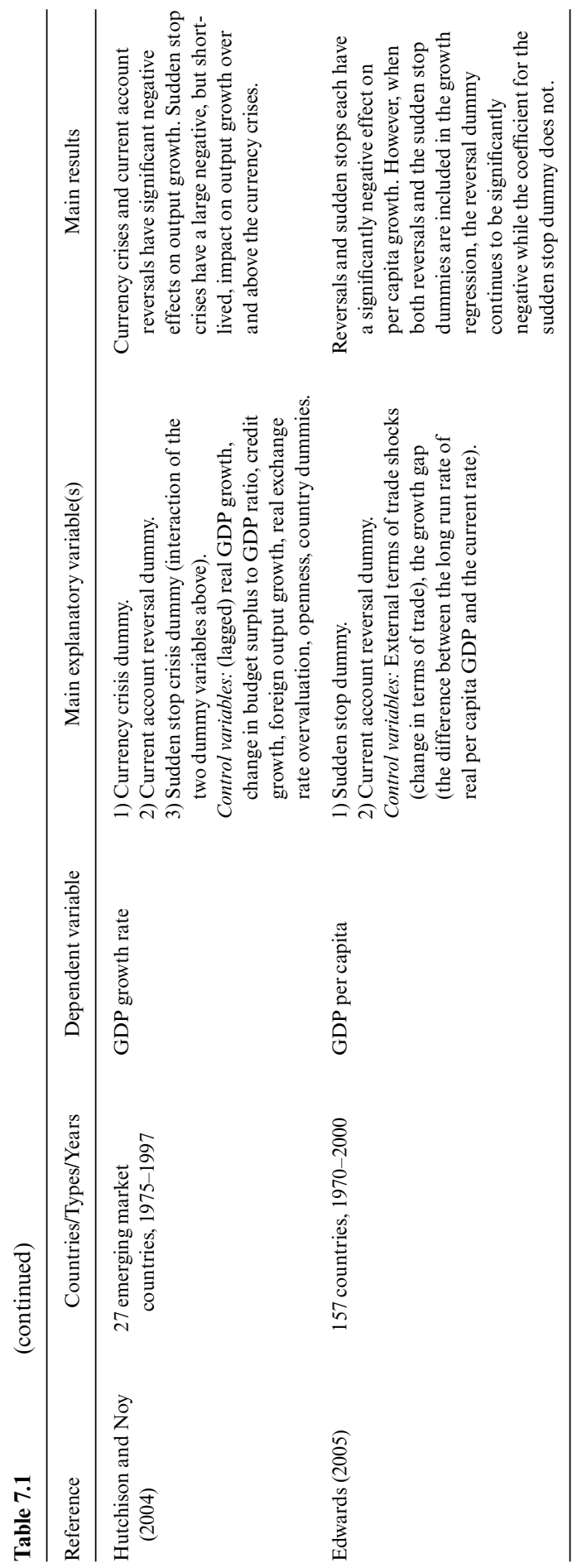




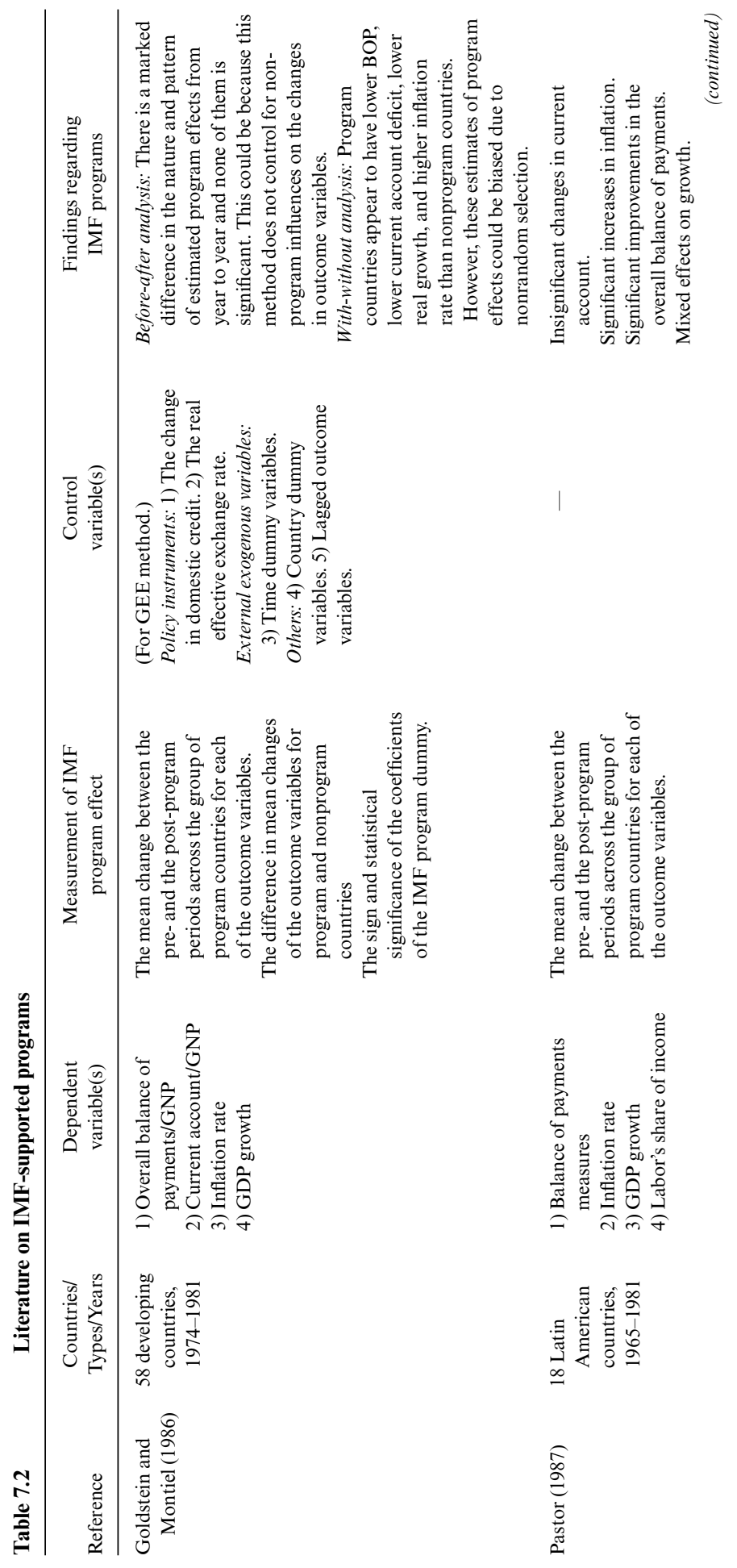




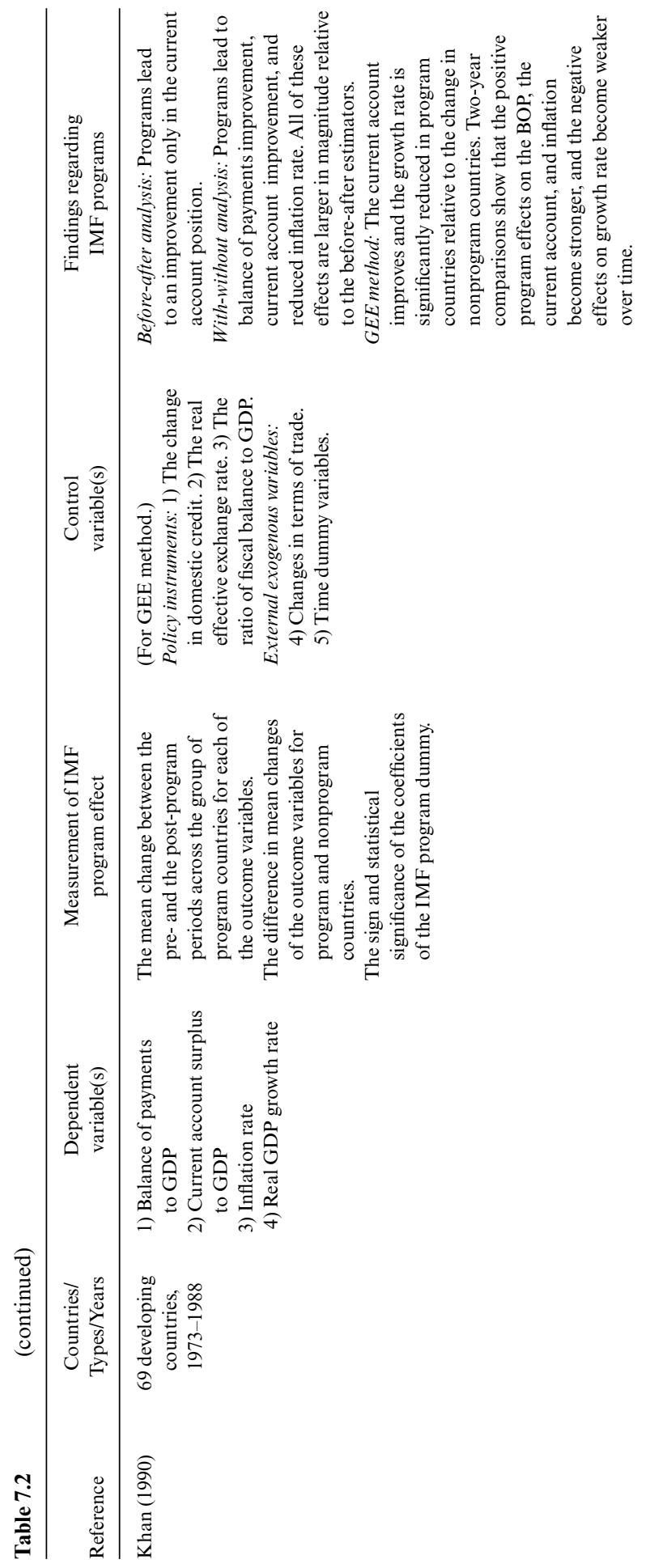




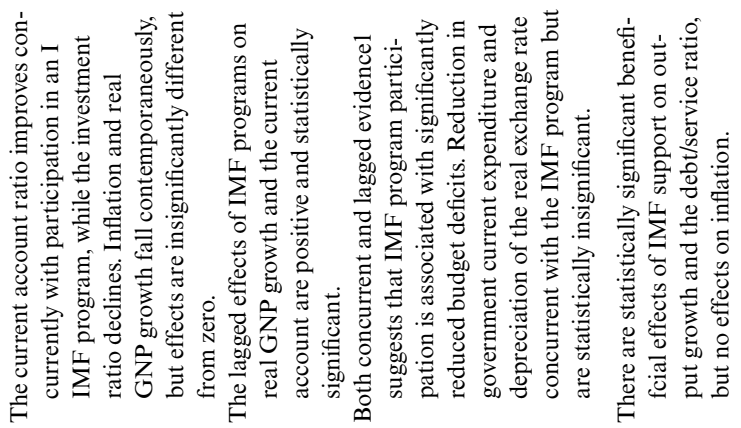
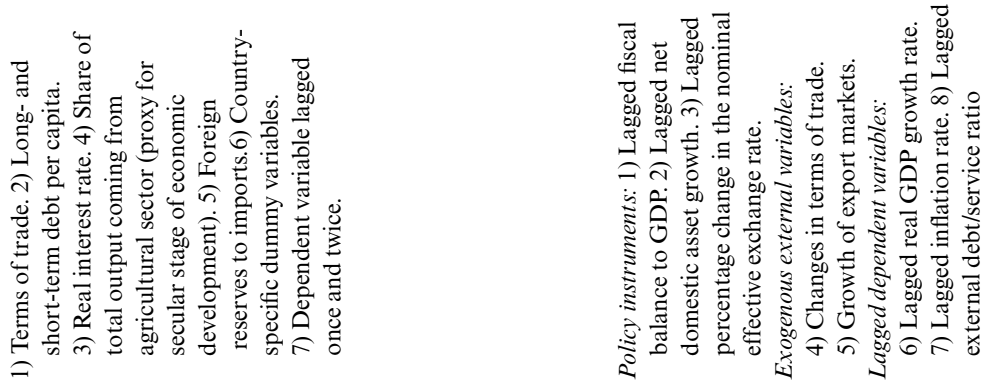

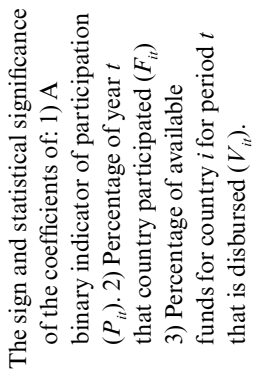
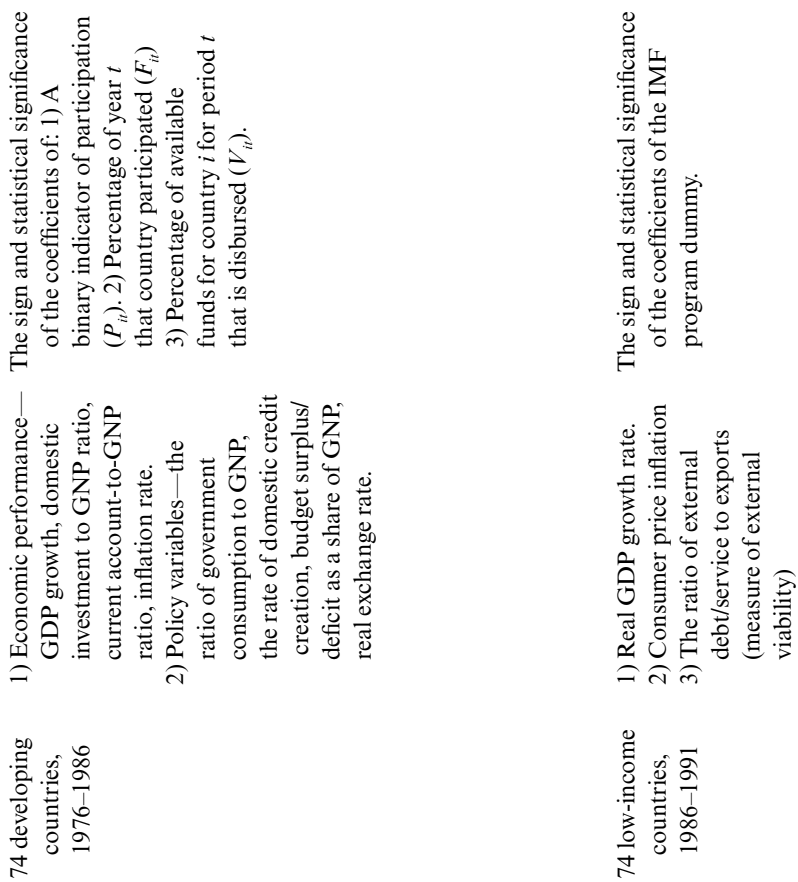

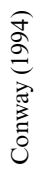

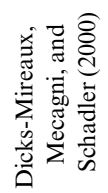




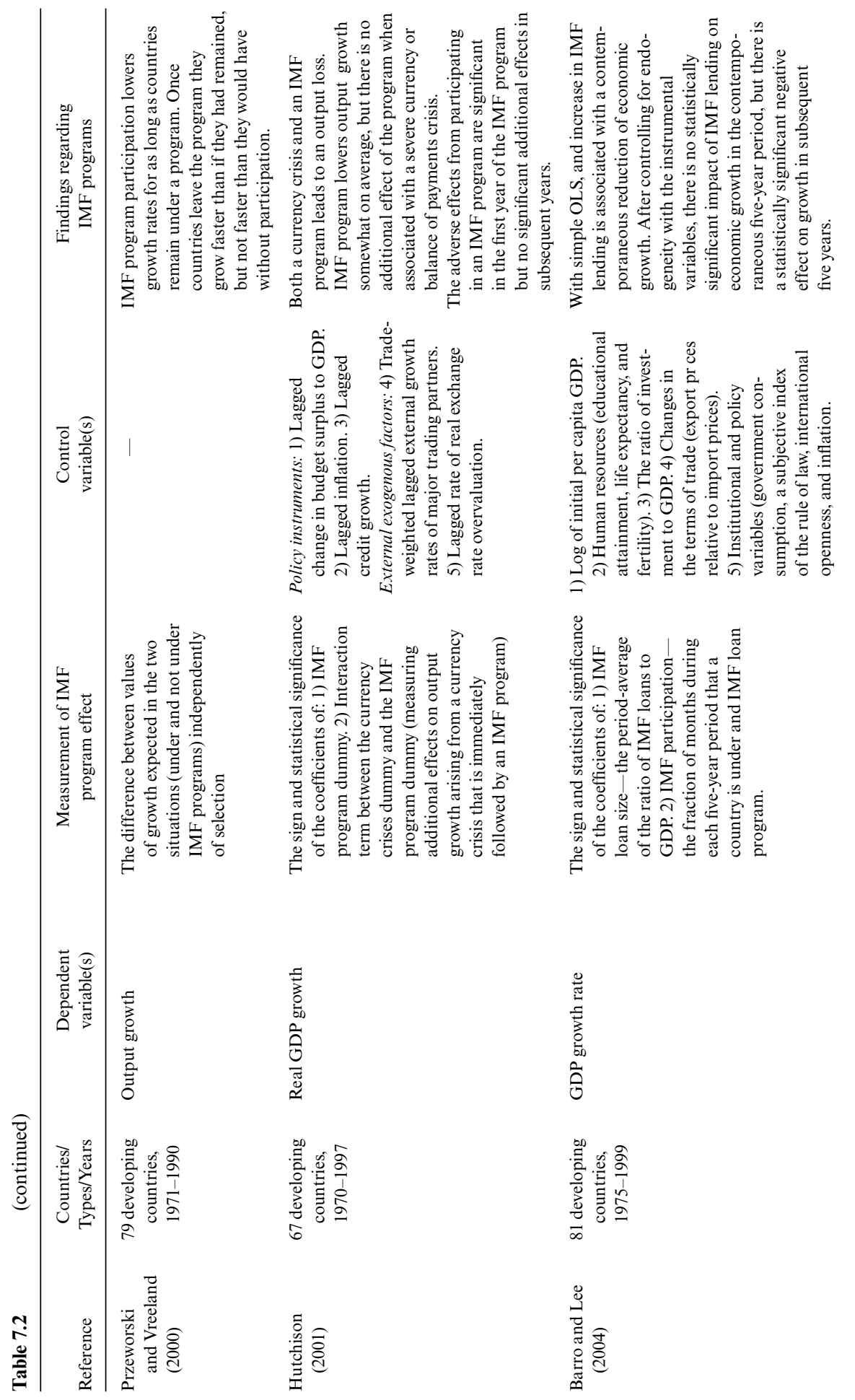




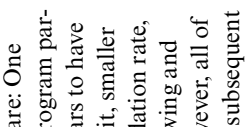

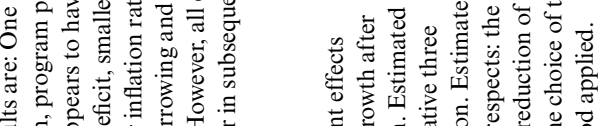

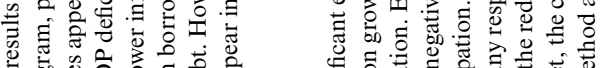

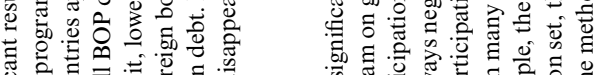

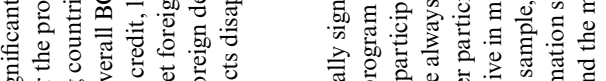

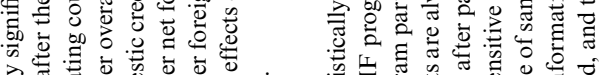

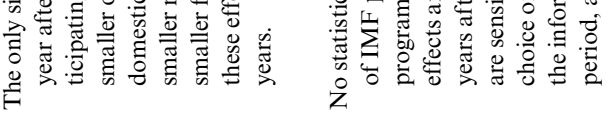
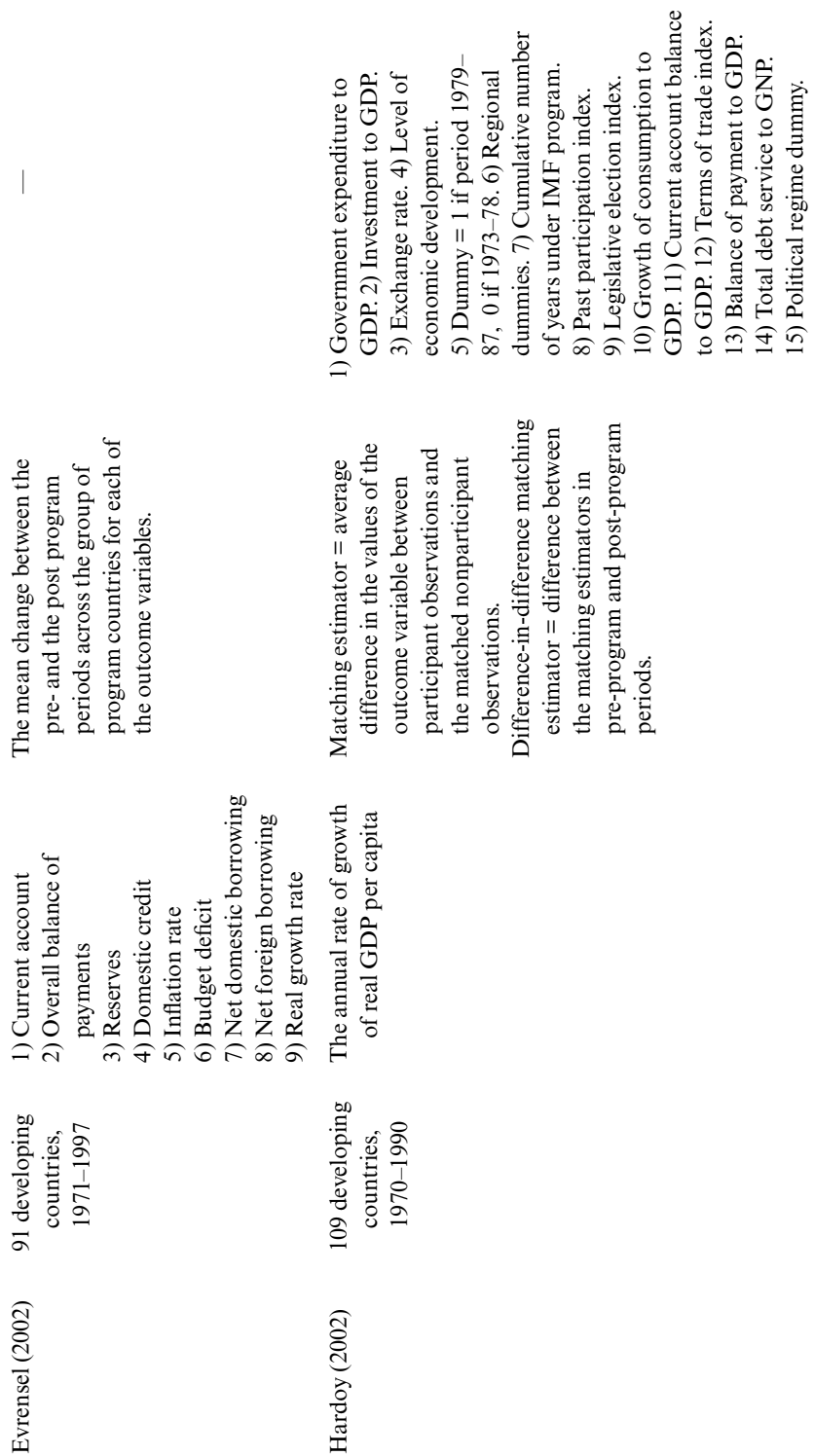


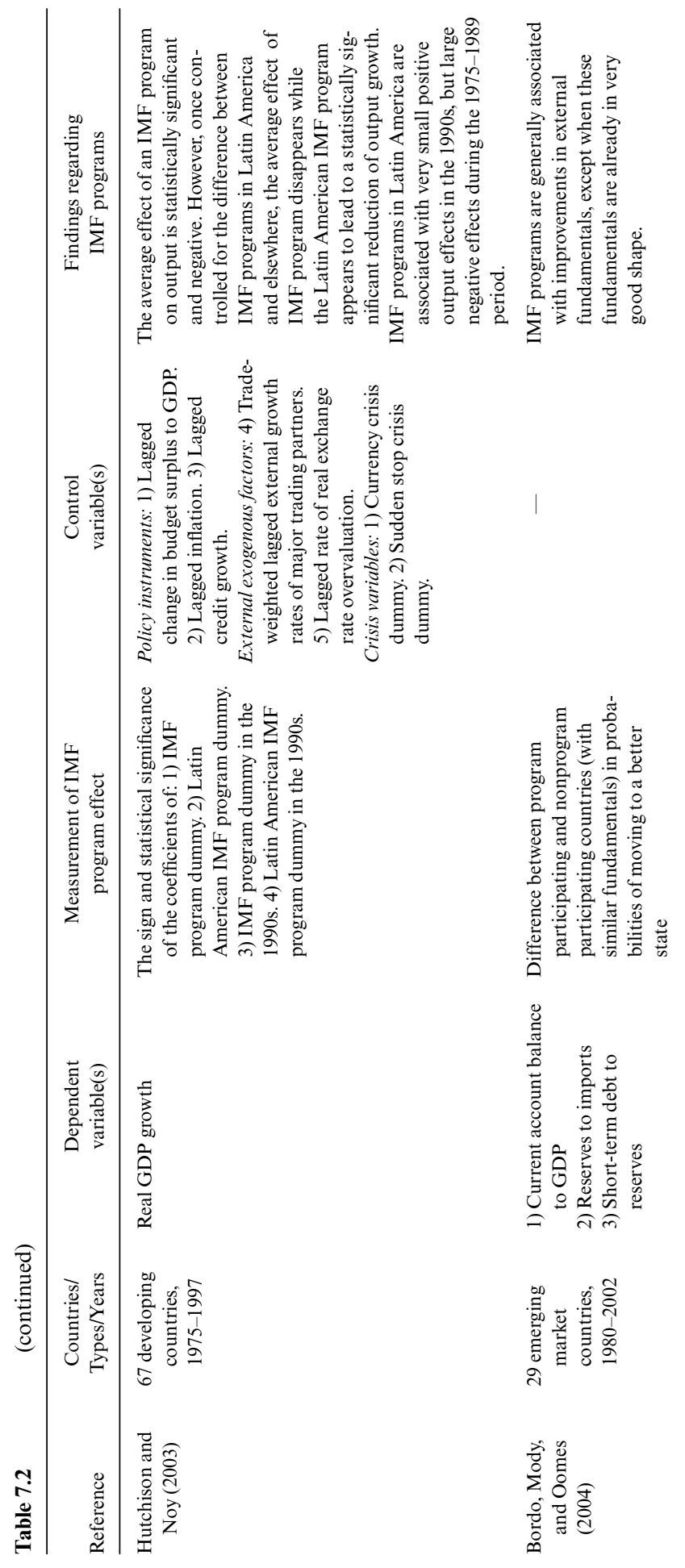



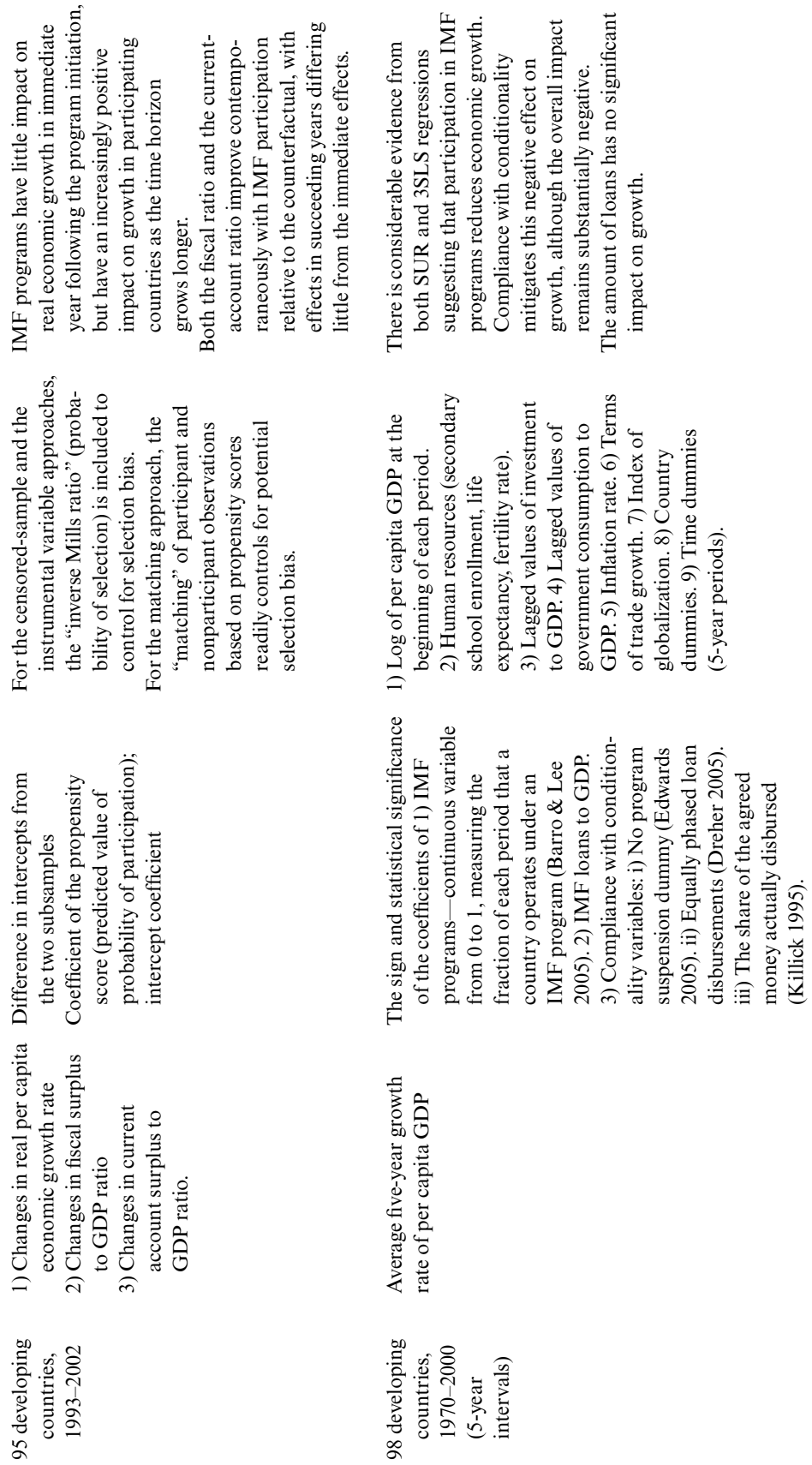

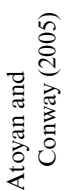


incidence would likely decline with the stepped-up provision of multilateral insurance. Calvo (2005) takes the often rapid recovery of growth from sudden stops as evidence that country policies are not at the root of this phenomenon. He concludes that sudden stops in emerging market countries reflect inefficiencies in international financial markets and argues for emergency financial assistance to countries suffering sharp interruptions in capital flows. ${ }^{2}$

A number of questions can be raised about this argument. One is why countries cannot obtain insurance by establishing credit lines on international capital markets or issuing securities with embedded options that have the same insurance properties. If the argument for insurance is strong, then the private sector should be prepared to provide it for a fee. This objection seems especially compelling in light of the recent growth of international financial markets and transactions. It is not clear why contracting for private insurance is not more widespread. ${ }^{3}$

- One possible explanation is that capital requirements and other regulations prevent potential suppliers from providing insurance on the requisite scale. Commercial counterparties may also be worried about concentrated country exposures and demand a prohibitive price for the provision of contingent credit lines. Still, if the case for private insurance is strong, financial markets and institutions adept at diversifying and repackaging risks should find a way around these obstacles.

- Another possibility is adverse selection. If asymmetric information prevents potential insurers from discriminating among borrowers in different risk categories, then only risky countries will wish to contract for such lines. The higher are the fees and interest rates charged, the greater will be the riskiness of willing clients, causing the private market to collapse. The limitation of this argument is that insurers are far from ignorant of variations in country risk. Thus, while information asymmetry is a concern, especially when crisis conditions begin to develop, lenders should still be able to establish ex ante differences in charges for borrowers subject to different levels of country risk. ${ }^{4}$

2. Calvo's preferred variant of the mechanism would have the stabilization fund purchase the bonds of adversely affected economies to prevent their spreads from rising (Calvo 2002).

3. There has, in fact, been some experimentation with private insurance by, inter alia, Argentina in the 1990s. (The experiment in question involved a contingent repurchase contract between the Argentine central bank and a consortium of foreign banks, under which the central bank was allowed to withdraw funds in the event of a crisis via a renewable credit line collaterialized by dollar-denominated government bonds.) But the Argentine credit line was small, and execution was delayed until well into the crisis. There is also the recent development of credit derivatives markets, which offer the possibility of purchasing protection against a range of emerging market credit events, although data on these markets are hard to come by. This is especially true of their use-for obvious reasons - by emerging market sovereigns.

4. A related argument is that a public insurance agency may have more ability or stronger incentives to gather information on the financial condition of its clients, in turn enabling it to 
- Yet another possibility is that commercial insurance providers have an incentive to take a short position against the country when the latter is likely to draw down its credit line. In turn this will destroy the effectiveness of the insurance (Broda and Levy Yeyati 2003). Presumably this problem does not carry over to public insurance providers. ${ }^{5}$

A second question is whether bunching - that multiple countries tend to experience sudden stops simultaneously - limits the feasibility of multilateral insurance. If a substantial subset of IMF members needs to draw on the resources of the Fund simultaneously because they experience shocks simultaneously, then the financial feasibility of an insurance arrangement may be questionable.

A third question is whether it is, in fact, correct that sudden stops are not really a function of country policies. Empirical analyses from Calvo, Izquierdo, and Mejia (2004) to Edwards (2005) identify roles for both internal and external factors. ${ }^{6}$ Insofar as the relevant characteristics include policies under the control of the domestic authorities, this means that the moral hazard problem must be addressed. ${ }^{7}$

Moral hazard does not render insurance infeasible, but it requires that a reasonable insurance scheme be designed to limit its extent. An obvious way of doing so is through surveillance and conditionality. A key question is whether such conditions are better applied ex post or ex ante. Specifically, should the IMF announce in advance what countries are eligible for

better tailor incentive-compatible contracts. The obvious objection here is that private financial institutions with their own performance at stake have at least as strong an incentive to invest in these monitoring functions.

5. This problem would be ameliorated if the insurance liability was securitized and widely distributed as diversification would then provide the insurers with the protection they need (obviating the need to hedge on a large scale). But in turn this begs the question of why emerging market countries find it hard to place innovative securities containing put and call options that kick in, reducing debt service or even calling for reverse payments, when economic conditions deteriorate.

6. To quote Calvo $(2005,26)$, "Econometric studies do not reject the hypothesis that Sudden Stops are largely prompted by external factors but, at the same time, strongly suggest that the probability of Sudden Stops reflects domestic characteristics." In other words, even analysts emphasizing the importance of global factors acknowledge that domestic characteristics shape the impact and response to external shocks.

7. The extent and economic importance of moral hazard in this context is disputed; for a review of the evidence, see Lane and Phillips (2000). There is also the possibility that, in the presence of other distortions, adding insurance will lead to less risk taking rather than more. Thus, in a model of finite-lived governments, where the probability of government survival declines with the incidence of financial crises, Cordella and Levy Yeyati (2004) show that insurance, by reducing the risk of financial collapse, may in fact encourage the authorities to invest more in policy reform (in the present context, to reduce the riskiness of their policies). Of course, there are actually two effects of insurance here: insurance reduces the pressure on the government to head off a crisis, but it also strengthens the incentive to pursue reforms that pay off in the future. Predictably, the net effect is ambiguous. Cordella and Levy Yeyati show that insurance is more likely to encourage reforms that pay off in good times (because it reduces the risk of falling into a crisis in the first place) than reforms that reduce the risk of a crisis in the event that one occurs. 
a credit line and specify the amount of assistance that they can expect to receive? Or should it proceed on a case-by-case basis and decide whether to provide additional credit once the sudden stop and the severity of the output decline have been observed?

Those who argue for insurance against sudden stops generally favor ex ante contracts. First, the problems of illiquidity that arise when capital flows are interrupted can lead to problems of insolvency unless funds are disbursed quickly. Determining eligibility quickly requires that countries be deemed eligible for assistance ex ante. Second, if the terms and amounts of external assistance are specified ex ante, then the government has a stronger incentive to take steps to expedite the economy's recovery from the sudden stop.

Cohen and Portes (2004) describe an insurance contract in which countries prequalify for assistance if their debt ratios remain below a critical ceiling consistent with moderate spreads, say 400 basis points above London Interbank Offered Rate (LIBOR). By assumption, any crisis that the country then experiences is a crisis of liquidity, not a crisis of debt sustainability. Payments are triggered when spreads on the debt rise above the threshold level. The IMF would then lend to the country at the threshold spread. It would thus contain the effects of the sudden stop that caused spreads to rise and prevent the liquidity crisis from degenerating into a solvency crisis. Cordella and Levy Yeyati (2005) propose a country insurance facility that would provide eligible countries with automatic access to a credit line at a predetermined interest rate, where eligibility criteria would again focus on debt sustainability — not just the level of the debt but also its maturity and currency composition. Dervis and Ozer (2005) similarly propose a Stability and Growth Facility that would provide insurance against unforeseen shocks and for which countries would prequalify on the basis of their policies.

Chami, Sharma, and Shim (2004) provide a model laying out the analytics of this approach. They assume that the insurer has two objectives: safeguarding its assets and providing for the borrowing country's welfare, which it can enhance by extending a loan. A governmental counterparty decides in each of two periods how much unobserved effort to exert in order to avoid and, if necessary, recover from a financial crisis, which in turn affects how much will be asked to repay to the insurance pool.

In this model it is preferable for the insurer to specify eligibility and the terms of the credit line-how much assistance will be extended as a function of the severity of the decline in output that occurs in the first periodbefore the country enters a crisis and the full output consequences are revealed. Knowing that it stands to receive official support, the efforts of the national authorities to avert the crisis are correspondingly less. But the extent of the moral hazard affecting the authorities' efforts to recover from the 
crisis varies with the form of the contract. Under an ex post contract, the crisis country repays more if it makes a greater effort to recover from the crisis, which works to depress adjustment effort. In contrast, under the ex ante contract, when terms are agreed prior to the government's decision of how much adjustment effort to extend, repayment is independent of effort; hence adjustment will be greater, and outcomes will be superior. In general, an insurer that both has a fiduciary responsibility to safeguard its assets and that cares about the welfare of the crisis country will prefer an ex ante contract in which the operator of the reserve pool specifies who is eligible and the terms and amounts of the assistance that will be forthcoming.

But there may be a problem of time consistency with the ex ante contract. The insurer may want to renege on its fixed commitment if it observes that the recession is unusually severe. Because it values the welfare of the insured, it may then wish to offer more generous terms. Hence ex ante contracts fixing the amount and terms of the credit line will not be credible. And because the insured knows this, moral hazard lending to less adjustment effort will still be a problem, surveillance and conditionality or not. ${ }^{8}$

This suggests that the IMF may wish to deem certain countries eligible for a fixed credit line as this is better than a discretionary, case-by-case approach at preserving its financial solvency, while at the same time supporting the welfare of its members, but that the time-consistency problem may undermine the feasibility of this approach and aggravate moral hazard. And if moral hazard is serious, such an insurance arrangement may turn out to be welfare reducing rather than welfare improving for the membership as a whole.

Two further questions can be raised about these ideas. First, doesn't the unsatisfactory experience of the IMF's contingent credit line (CCL), for which no country applied prior to its expiration in 2003, raise questions about the enthusiasm of countries for ex ante insurance? Insofar as executive directors have a responsibility for the IMF's own solvency, members running risky policies that may prevent them from paying back credits would have to be denied the privilege of borrowing. Such an outcome would send a negative signal to the markets. This seems to have been what deterred governments from applying for a CCL. A further problem was that eligibility could be rescinded at some future date, sending a negative signal that might precipitate a crisis.

The Fund could meet its fiduciary responsibility by announcing unilaterally which members were eligible for financial assistance. But it would then send a negative signal about the financial condition of other countries when it declared them ineligible for insurance. In turn this might render

8. Theoretically, this problem could be solved by repeated interaction between the insurer and the country, through which the former develops a reputation for acting consistently. 
countries reluctant to participate in the insurance arrangement in the first place. And the exit problem would remain. ${ }^{9}$

Finally, such schemes assume the ability of the agency operating the facility to discriminate between solvent and insolvent countries, where the solvent countries are still susceptible to liquidity crises and should thus be made automatic beneficiaries of the new facility. Cohen and Portes (2004) assume the existence of a well-defined amount of debt that forms the ceiling on what is sustainable and a stable linkage running from debt levels to spreads. Cordella and Levy Yeyati (2005) argue that a ceiling should be defined for the overall debt-gross domestic product (GDP) ratio but also recommend that foreign-currency debt and short-term debt should receive heavier weights in the calculation of this total. They suggest imposing a ceiling on the fiscal deficit in each of the preceding three years.

In the real world, sustainability depends on forecasts of future growth rates and interest rates that are disputable and uncertain. It depends on estimates of the political will of a government and society to mobilize and transfer resources for purposes of debt service. Given this uncertainty, it seems unavoidable that any insurance facility will occasionally lend to countries that find it impossible to repay. Or it will not lend to countries whose problems are liquidity related, leading to complaints and recrimination. Any automatic scheme that depends on the existence of an operational distinction between insolvent and illiquid crisis countries is unlikely to be feasible in practice. ${ }^{10}$

\subsection{Capital Flows and Sudden Stops}

As our measure of capital flows we use the financial account balance, a summary measure of net capital flows that includes net foreign direct investment, net portfolio investment, and other investments. The advantage of this measure is its comprehensiveness; in principle, it should capture net capital flows of all kinds. ${ }^{11}$ One exception is that it does not include official

9. Cordella and Levy Yeyati (2005) suggest "smoothing" the eligibility criteria so that exogenous shocks temporarily pushing a country above the eligibility threshold do not precipitate a sudden jump in interest rates or a crisis. While this might help for small exogenous shocks that the authorities wish to offset, it will not help for large exogenous shocks that cannot be offset in the medium term.

10. This argument is developed and defended at greater length in Eichengreen (2000).

11. Other investigators, presumably with stronger priors about which capital flows are the primary source of instability, have focused on narrower measures (considering only financial flows for example) or on the change in gross rather than net inflows. Some have adjusted their preferred measure of capital flows for identifiable exogenous shocks to the current account (exports, the terms of trade, etc.). Some will argue for the exclusion of foreign direct investment (FDI) from the capital flow measure on the grounds that FDI flows are more stable and less prone to sudden stops. However, this conclusion is not universally accepted (for a flavor of the debate, see, e.g., Sarno and Taylor 1999). If FDI inflows fall dramatically, this is as much a problem for capital-importing countries as if portfolio inflows fall abruptly. This approach is not without implications for our sample of sudden-stop cases; see note 16. 
transfers associated with IMF programs, a fact that is important for what follows.

Following Calvo, Izquierdo, and Mejia (2004) and Cavallo and Frankel (2004), we consider both the first and the second moments of the capital flow series in identifying sudden stops. First, we identify the years where the financial account balance exhibited a large decline relative to its longterm average. We require this to be a large discrete drop and not just a correction of a large temporary inflow. Second, we calculate the mean and one-standard-deviation band of the financial account balance using the data up to the years identified in the first stage as potential sudden stops and retain only years that qualify on the basis of this criterion. ${ }^{12}$ Other authors have used two-standard-deviation bands, but because we are using annual data, a two-standard-deviation criterion turns out to be very strict.

Our empirical analysis focuses on emerging market countries significantly involved with international capital markets. For the period 1980 to 2003, we identified twenty-four such countries (listed in appendix A), which in turn experienced thirty-five sudden stop episodes. ${ }^{13}$ Our dates are very similar to those of Calvo, Izquierdo, and Mejia (2004) and Cavallo and Frankel (2004). However, they differ from those of Edwards (2005), where a sudden stop is said to occur when a country had previously been receiving significant capital inflows (where it ranked in its region's third quartile in terms of capital inflows in the two previous years) and their volume declines by at least 5 percent of GDP in a given year. This is a lenient criterion that tends to capture episodes where the financial account balance declines only from, say, 20 percent to 15 percent of GDP, as well as episodes where there is a correction of a temporary increase in the balance the year before. ${ }^{14}$

For this group of countries we present descriptive statistics for the twenty-four year period 1980 to $2003 .{ }^{15}$ In our sample, there a 5.5 percent

12. The moments were calculated using data up to the crisis year and not including the potential crisis year.

13. The "significant contact with international capital markets" criterion means that not all countries feature for the full length of the period. Thus, of the countries that transitioned from central planning, we include only Hungary and Poland and only after 1990, when they had moved significantly toward functioning markets. We include Bangladesh, Bolivia, Ghana, and Pakistan, which were recipients of concessional finance and were not as exposed to large market-based capital inflows. But even if these last four countries are dropped from the regression analysis, our findings remain robust, as we report in the following.

14. We note the omission from this list of a couple of cases - Russia and Brazil in 1999that feature prominently in qualitative discussions of capital market disruptions. For Russia, the short time series precluded the estimation of a reliable measure of standard deviation of the financial account. Brazil in 1999 is a close call by our measure; in this instance, the decline in portfolio and bank flows was offset by an increase in FDI, cushioning the decline in the financial account. In the section on robustness checks in the following, we show that the key results remain the same when we treat these observations as sudden stop cases.

15. For purposes of regression analysis, however, we concentrate on the period 1990 through 2003, when capital flows to emerging market countries, bond-market intermediated 


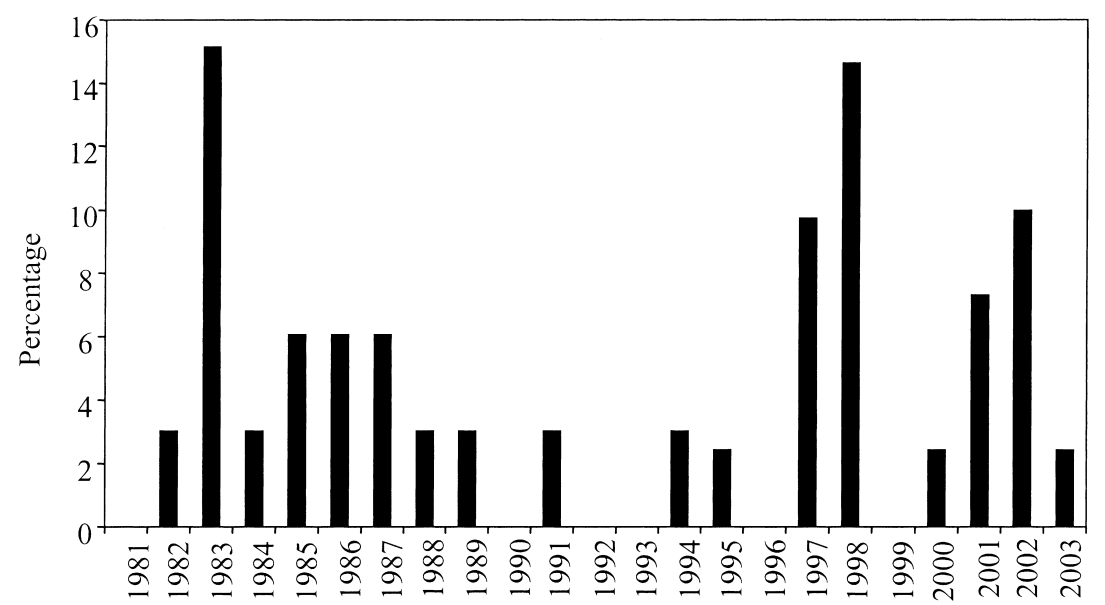

Fig. 7.1 Year-wise probability of a sudden stop

Source: Authors' calculations.

probability of a sudden stop in a given country in a given year. Figure 7.1 shows the time profile of these events. There is a clear bunching of sudden stops, as emphasized by Calvo (2005). Peaks coincide with the $1982 \mathrm{debt}$ crisis, the Asian crisis of 1997, and the aftermath of the Argentine crisis in 2002. Typically, countries experience a net capital outflow on the order of 5 percent of GDP in the first year of a sudden stop episode (figure 7.2). The swing in the net portfolio capital flow is on the order of 2 percent of GDP. In contrast, there is no discernible impact on net FDI flows. ${ }^{16}$ By implication, net capital outflows consist mostly of other forms of capital, such as funds channeled through the banking system, commercial credits, and so forth (see also table 7.3).

Typically, countries experiencing a sudden stop also experience an improvement in the current account balance on the order of 4 percent of GDP (figure 7.3). Note that we are not looking here at "current account reversals," where a current account reversal is typically defined as an episode when there is a large reduction in the size of an existing current account

flows in particular, were especially prominent. It is this subperiod that is most relevant for thinking about the future. Calvo, Izquierdo, and Mejia (2004) also consider the period since 1990. They draw a sample of fifteen emerging market economies and also include seventeen developed economies in their sample. By using monthly data, they are able to increase the number of their observations. Note that to ensure that our findings are not dictated by the period considered, in the section on robustness checks we also present regressions covering a longer period.

16. Recall that in the preceding we addressed the question of whether it was appropriate to include changes in net FDI in our measure of sudden stops and argued that the answer is yes on the grounds that one should not prejudge the stability of different forms of imported capital. Figure 7.2 suggests that this procedure does not have strong implications for our findings. 

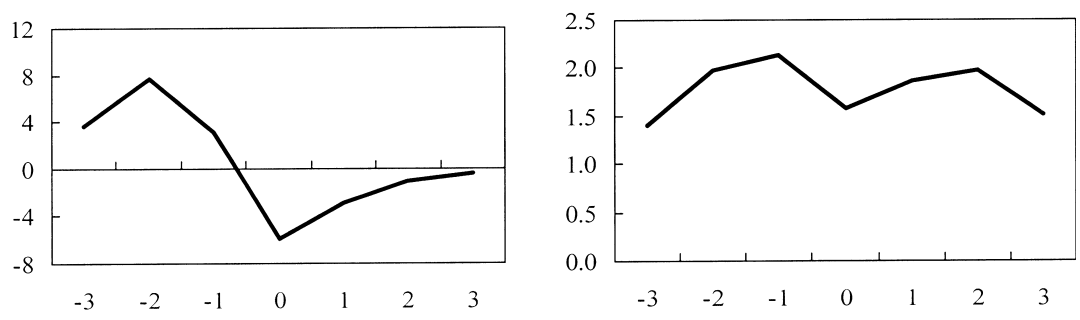

Net Portfolio Flows

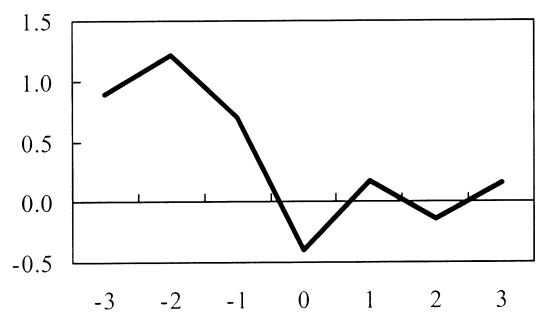

Net Other Flows

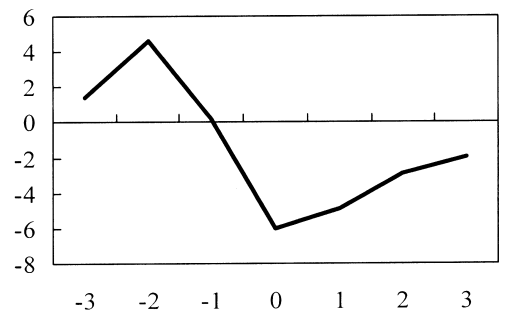

Fig. 7.2 Magnitude and composition of financial flows (in percent of GDP): $A$, Financial account balance; $B$, Net FDI flows; $C$, Net portfolio flows; $C$, Net other flows

Source: Authors' calculations.

Table 7.3

Magnitude and composition of capital flows during and prior to sudden stops (percentage of GDP)

\begin{tabular}{lcc}
\hline & $\begin{array}{c}\text { Three year average } \\
\text { prior to a sudden stop }\end{array}$ & $\begin{array}{c}\text { During the first year } \\
\text { of a sudden stop }\end{array}$ \\
\hline Total net financial inflows & 4.2 & -4.6 \\
Net FDI & $(6.8)$ & $(4.8)$ \\
Net portfolio flows & 1.5 & 1.2 \\
& $(1.9)$ & $(1.6)$ \\
Net other capital flows of which: & .62 & -.21 \\
& $(1.5)$ & $(1.46)$ \\
Net government flows & 2.1 & -5.6 \\
& $(6.5)$ & $(4.6)$ \\
Net banks flows & .52 & -1.2 \\
& $(2.8)$ & $(3.5)$ \\
Net other flows & .82 & -2.0 \\
& $(3.6)$ & $(3.0)$ \\
\end{tabular}

Note: Standard deviations are given in parentheses. 

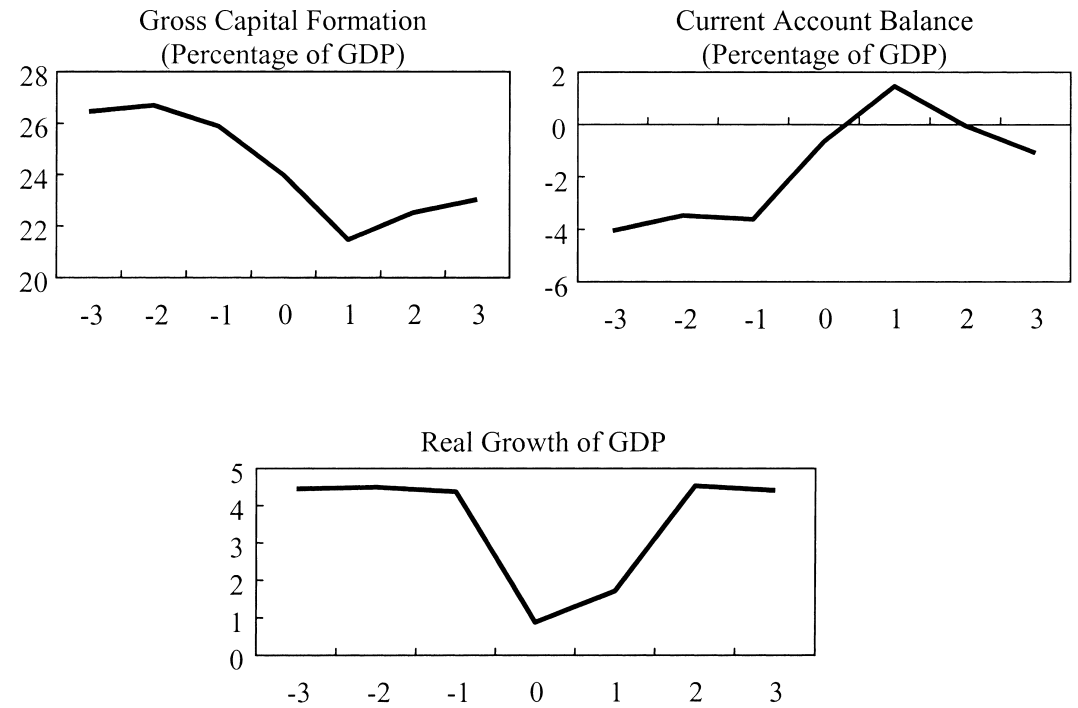

Fig. 7.3 Macroeconomic effects of sudden stops: $A$, Gross capital formation (percentage of GDP); $B$, Current account balance (percentage of GDP); $C$, Real growth of GDP

Source: Authors' calculations.

deficit; rather, we are summarizing the average behavior of the current account balance in our episodes of capital account reversal. The current account being the difference between savings and investment, the consequences are necessarily reflected in these variables. Figure 7.3 shows that the action is mainly on the investment side - that capital formation declines sharply. It follows that GDP growth is close to zero although it rebounds after one year. A statistical summary of these patterns is in table 7.4.

Sudden stops are also not the same as currency crises. For comparison, we use crisis dates from Kaminsky and Reinhart (1999), Berg and Patillo (1999), Frankel and Rose (1996), and Milesi-Ferretti and Razin (1998). ${ }^{17}$ Only about one-third of the sudden stops in our sample are associated with contemporaneous currency crises (see the first panel of table 7.5). The picture is the same when we lag the currency crises (as in the second panel of table 7.5). While we have fewer observations for banking crises, a larger share of sudden stops (about a half) appears to coincide with banking crises (see third panel of table 7.5). ${ }^{18}$

17. For recent years we supplement these with the dates from Frankel and Wei (2004). These data are merged following the procedures in Gupta, Mishra, and Sahay (2003).

18. This suggests a complex relationship between sudden stops, currency crises, and banking crises - which we leave for another paper. 
Table 7.4

Real effects of sudden stops

\begin{tabular}{lcc}
\hline & $\begin{array}{c}\text { Three year average } \\
\text { prior to a sudden stop }\end{array}$ & $\begin{array}{c}\text { During the first year } \\
\text { of a sudden stop }\end{array}$ \\
\hline Current account balance (\% of GDP) & -4.2 & -0.20 \\
Real growth & $(5.2)$ & $(6.2)$ \\
& 3.7 & 0.39 \\
Export growth & $(4.2)$ & $(5.5)$ \\
& 1.2 & 1.2 \\
Capital formation (\% of GDP) & $(5.4)$ & $(4.1)$ \\
Fixed capital formation (\% of GDP) & 25.3 & 22.5 \\
& $(7.4)$ & $(6.9)$ \\
& 23.8 & $(6.5)$ \\
\hline
\end{tabular}

Note: Standard deviations are given in parentheses.

Table 7.5 Sudden stops and banking and currency crises

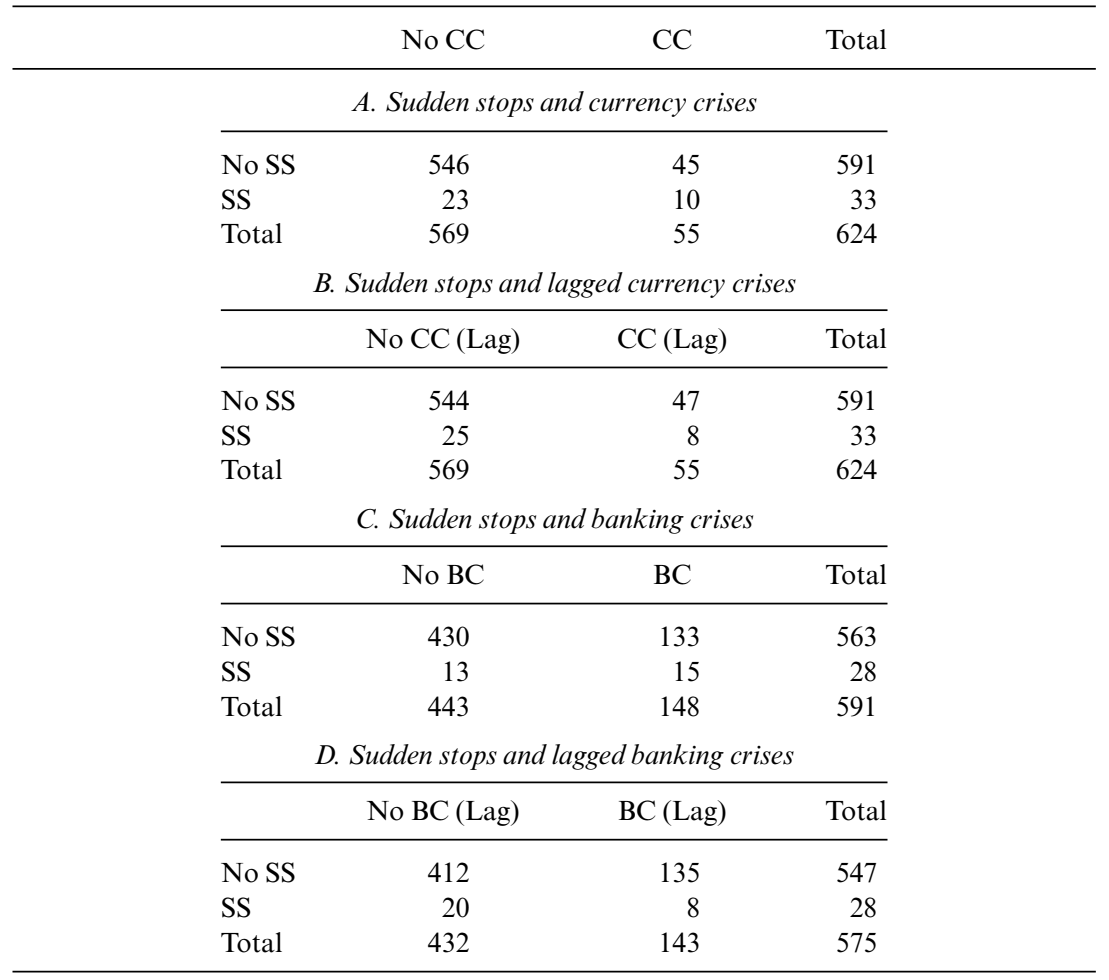

Note: $\mathrm{SS}=$ sudden stops $; \mathrm{BC}=$ banking crises $; \mathrm{CC}=$ currency crises. 


\subsection{IMF-Supported Programs}

Information on IMF programs is drawn from a data base maintained by the Fund's Policy Development and Review Department. We have information on the years in which a program started and ended, whether it was precautionary from the outset or turned precautionary in the course of its operation, the value of the funds approved, and the amount used under the program. (Under precautionary programs, the IMF and the country agree on conditionality and monitoring, but the country declares its intention to not draw on resources from the Fund, though this declaration is not binding.) Slightly more than 12 percent of the Fund programs in our sample were precautionary from the start. ${ }^{19}$

Table 7.6 is a first look at the association of Fund programs and sudden stops. We differentiate between "new" programs initiated in either of the two years prior to the sudden stop, and "existing" programs in place in still earlier years. ${ }^{20} \mathrm{In}$ approximately a third of sudden stop cases, a new IMF program was negotiated in one of the two years immediately preceding the sudden stop, and in 20 percent of the sudden stop cases a program was already in place in still earlier years. Whereas the unconditional probability of a sudden stop in our sample is 5.5 percent, the probability of a sudden stop is about 1 percentage point lower if an IMF program was in place (whether the program was contracted in the two immediately preceding years or existed previously). This with and without IMF program differential is more pronounced if we limit ourselves to data for the period after 1989.

The raw data are consistent with the idea that whether a Fund program is in place matters for consumption, the trade balance, and the current account. Here the averages (in figure 7.4) refer to all programs, whether initiated in the two years immediately preceding the crisis or prior to that. Program countries indicated by the broken line receive access to credit from the IMF that enables them, not surprisingly, to run larger current account deficits (or smaller surpluses) and to maintain higher levels of consumption. The impact on the other variables is unclear. Program countries appear to enjoy more stable portfolio capital flows following the sudden stop,

19. We use the outstanding amount of the credit disbursed. The alternative is to use the "approved" lending amount, that is, the amount that a country can draw on. The approved amount has the advantage of measuring the prospective envelope of resources. However, the country must go through a review process to access those resources. In practice the results were more robust when we used the outstanding credit variable. The implication is that where programs were precautionary and no amounts were disbursed, IMF credit should take on a value of zero. This is the approach we use to testing separately for the influence of precautionary programs in what follows. Finally, because the outstanding credit also includes funds borrowed by a country under concessional credit programs, we check in our robustness analysis if dropping those countries (Bangladesh, Bolivia, Ghana, and Pakistan) makes a difference to our results (the answer is that it does not).

20 . The rationale for this will become clear in the following. 
Table 7.6

IMF-supported programs and sudden stops: Number of sample observations

\begin{tabular}{cccc}
\hline & \multicolumn{2}{c}{ IMF Program } & \\
\cline { 2 - 4 } Sudden Stop & No & Yes & Total \\
\hline A. New IMF-supported & programs and sudden & stops $(1980-2003)$ \\
No & 396 & 256 & 652 \\
Yes & 26 & 13 & 39 \\
Total & 422 & 269 & 691 \\
B. New or existing IMF-supported programs and sudden stops & $(1980-2003)$ \\
No & 300 & 373 & 673 \\
1 & 21 & 18 & 39 \\
Total & 321 & 391 & 712 \\
C. New IMF-supported programs and sudden stops (1990-2003) & \\
No & 261 & 148 & 409 \\
Yes & 18 & 6 & 24 \\
Total & 279 & 154 & 433 \\
Dew or existing IMF-supported programs and sudden stops & $(1990-2003)$ \\
No & 185 & 224 & 409 \\
Yes & 15 & 9 & 24 \\
Total & 200 & 233 & 433 \\
\hline
\end{tabular}

but investment is no stronger, and the recovery of growth is not obviously superior.

\subsection{Multivariate Analysis}

We now present a regression analysis of the association of IMF programs with sudden stops, conditioning on other determinants of the change in the financial accounts and instrumenting for the endogeneity of the program variable. This section presents the benchmark regressions with just the conditioning variables. The choice of conditioning factors is important as omitting an important country-specific or global determinant of the risk of sudden stops creates the danger that we may incorrectly impute this risk to the presence or absence of an IMF program.

We construct the dependent variable two ways: first, as a simple binary indicator equaling one in the first year of a sudden stop; second, as the financial account balance if and only if a sudden stop occurred as a way of capturing the severity of the event. ${ }^{21}$ Regressions using the first dependent variable are estimated by probit (we report the marginal probabilities),

21. In addition to the financial account balance, we also look at the change in financial account balance in the year of the sudden stop as compared to the average of presudden stop years. The two measures are highly correlated, and the results are similar across the two measures. 

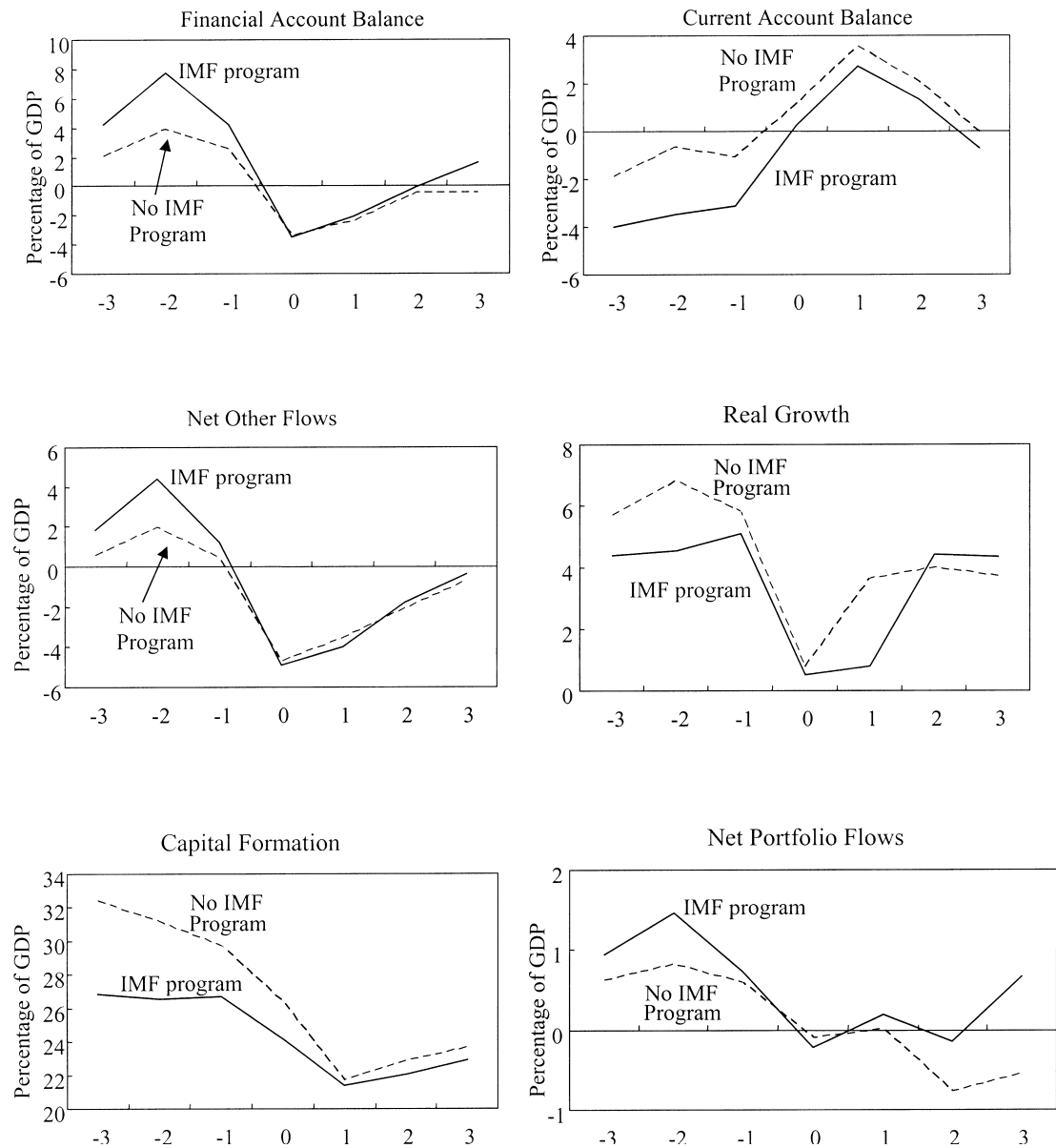

Fig. 7.4 IMF-supported programs and effects of sudden stops: $A$, Financial account balance (as percentage of GDP); $B$, Current account balance (as percentage of GDP); $C$, Net other flows (as percentage of GDP); $D$, Real growth; $E$, Capital formation (as percentage of GDP); $F$, Net portfolio flows (as percentage of GDP) Source: Authors' calculations.

while regressions using the second dependent variable are estimated by Tobit. In principle, the Tobit regressions should make more complete use of the available information. Country fixed effects are used throughout. But because we also use global time-varying variables, time-period fixed effects are not included in the analysis of sudden stops.

The benchmark regressions for the determinants of sudden stops in table 7.7 suggest that global factors matter, as emphasized by, inter alia, Calvo 


\begin{tabular}{|c|c|c|c|c|c|}
\hline \multirow[b]{2}{*}{ Dependent variable } & \multicolumn{5}{|c|}{ Indicator for the first year of sudden stop } \\
\hline & \multicolumn{4}{|c|}{ 1990-2003 } & 1984-2003 \\
\hline Treasury bill rate & $\begin{array}{r}0.007 \\
{[0.97]}\end{array}$ & & & & \\
\hline High yield spread & $\begin{array}{c}0.008 \\
{[1.36]}\end{array}$ & $\begin{array}{c}0.006 \\
{[1.08]}\end{array}$ & $\begin{array}{c}0.011 \\
{[1.61]}\end{array}$ & $\begin{array}{l}0.012^{*} \\
{[1.68]}\end{array}$ & $\begin{array}{c}0.013^{*} \\
{[1.88]}\end{array}$ \\
\hline Change in real oil prices & $\begin{array}{l}-0.001^{* * *} \\
{[3.29]}\end{array}$ & $\begin{array}{l}-0.001^{* * *} \\
{[3.08]}\end{array}$ & $\begin{array}{l}-0.001 * * * \\
{[2.98]}\end{array}$ & $\begin{array}{l}-0.002^{* * *} \\
{[3.10]}\end{array}$ & $\begin{array}{l}-0.001 \text { *** } \\
{[2.91]}\end{array}$ \\
\hline GDP growth & $\begin{array}{l}0.011^{* * *} \\
{[3.15]}\end{array}$ & $\begin{array}{l}0.012^{* * *} \\
{[3.11]}\end{array}$ & $\begin{array}{l}0.008^{* *} \\
{[2.12]}\end{array}$ & $\begin{array}{l}0.007^{* *} \\
{[1.99]}\end{array}$ & $\begin{array}{c}0.0001 \\
{[0.05]}\end{array}$ \\
\hline Trade balance/GDP & $\begin{array}{c}-0.006^{*} \\
{[1.73]}\end{array}$ & $\begin{array}{c}-0.006 \\
{[1.63]}\end{array}$ & $\begin{array}{c}-0.006 \\
{[1.51]}\end{array}$ & $\begin{array}{c}-0.007^{*} \\
{[1.74]}\end{array}$ & $\begin{array}{l}-0.008^{* * *} \\
{[2.70]}\end{array}$ \\
\hline Debt servicing/Exports & $\begin{array}{r}0.001 \\
{[1.64]}\end{array}$ & $\begin{array}{r}0.002 \\
{[1.64]}\end{array}$ & $\begin{array}{l}0.002 * \\
{[1.81]}\end{array}$ & $\begin{array}{l}0.002 * \\
{[1.89]}\end{array}$ & $\begin{array}{r}0.001 \\
{[0.99]}\end{array}$ \\
\hline Domestic credit/GDP & $\begin{array}{l}0.002^{* * *} \\
{[2.69]}\end{array}$ & $\begin{array}{l}0.002^{* *} \\
{[2.49]}\end{array}$ & $\begin{array}{l}0.002^{* *} \\
{[2.25]}\end{array}$ & $\begin{array}{l}0.002 * * \\
{[2.35]}\end{array}$ & $\begin{array}{l}0.002^{* * * *} \\
{[3.04]}\end{array}$ \\
\hline Change in domestic credit/GDP & $\begin{array}{l}0.004^{* * *} \\
{[2.99]}\end{array}$ & $\begin{array}{l}0.004^{* * *} \\
{[2.91]}\end{array}$ & $\begin{array}{l}0.005^{* *} \\
{[2.47]}\end{array}$ & $\begin{array}{l}0.005^{* * *} \\
{[2.72]}\end{array}$ & $\begin{array}{l}0.003^{* *} \\
{[2.05]}\end{array}$ \\
\hline Debt/GDP & $\begin{array}{l}0.003 * * * \\
{[2.87]}\end{array}$ & $\begin{array}{l}0.003^{* * *} \\
{[2.83]}\end{array}$ & & & \\
\hline Change in debt/GDP & $\begin{array}{r}0.001 \\
{[1.23]}\end{array}$ & $\begin{array}{r}0.001 \\
{[1.25]}\end{array}$ & $\begin{array}{r}0.001 \\
{[0.86]}\end{array}$ & & \\
\hline Country fixed effects & Yes & Yes & Yes & Yes & Yes \\
\hline Time fixed effects & No & No & No & No & No \\
\hline Pseudo $R^{2}$ & 0.26 & 0.26 & 0.21 & 0.20 & 0.17 \\
\hline No. of observations & 227 & 227 & 227 & 227 & 332 \\
\hline
\end{tabular}

Notes: Columns reporting probit results present marginal probabilities, based on the STATA command "dprobit." Robust $z$ statistics are presented in brackets.

***Significant at the 1 percent level.

**Significant at the 5 percent level.

*Significant at the 10 percent level.

(2005), although the obvious suspects are not always prominent. ${ }^{22}$ The U.S. high-yield spread (the spread over risk-free U.S. government bonds) is generally positive and on the margin of significance. The high-yield spread is often used as a measure of the global risk premium, with the implication that a rise in the risk premium can trigger reversals in capital flows to emerging markets. At its strongest, the coefficient estimate implies that

22. We do not claim that we provide here a definitive analysis of the role of global factors in sudden stops - nor do we attempt to do so, given that the available space is fully occupied by our analysis of the effects of IMF programs. But this deserves to be a high priority for future work on the feasibility of an insurance facility, insofar as the importance of common global factors is directly related to the capacity of the IMF as a financial pool to provide assistance to different countries experiencing sudden stops. 
every 100 basis point increase in this spread increases the probability of a sudden stop by between 1 and 1.5 percentage points. In contrast, the U.S. treasury bill rate is not significant. ${ }^{23} \mathrm{~A}$ somewhat surprising result is that an increase in the real price of oil appears to reduce the risk of a sudden stop - surprising because many emerging markets countries are net oil importers. However, not all emerging market economies are oil importers; indeed, some of those that have been historically most susceptible to sudden stops are substantial oil exporters. High oil prices tend to coincide with high commodity prices generally, and it is not surprising that emerging market countries, many of which are commodity exporters, enjoy larger and steadier capital inflows when commodity prices move in their favor. Moreover, a rise in oil prices also improves global liquidity because oil-rich nations run balance of payments surpluses that need to be reinvested, and this may work to the advantage of emerging market countries.

Among the country-specific factors, high and rising ratios of domestic credit to GDP are strongly associated with sudden stops, as emphasized in the credit-boom literature (IMF 2004). There is some suggestion that periods of rapid growth associated with credit expansions are likely to end in sudden stops. ${ }^{24}$ Presumably, some of these high credit growth episodes are fuelled by the inflow of foreign capital, which can reverse abruptly. A high ratio of debt to GDP (in levels but not rate-of-change form) also increases is vulnerability. A smaller trade balance and a larger ratio of debt service to exports increase the likelihood of a sudden stop. The message seems to be that the combination of a domestic credit boom and the emergence of external payment risks heightens the risk of a sudden stop.

A variety of sensitivity analyses left these basic results unchanged.

-We dropped the country dummies, thus adding cross-section variation, without significantly altering our findings. However, it remains the case that most of the variation in the dependent variable is still explained by within-country variations rather than by cross-country differences.

- Results for the longer period 1984 to 2003 , in the last column of table 7.7 , continue to produce qualitatively similar findings.

23. That the usual measures of global financial stress are not prominent in their explanation of the incidence of sudden stops is not necessarily inconsistent with their bunching in time. It is possible that measures of "common vulnerability" may attract the attention of international investors, causing them to retreat from a broad range of countries (see Mody and Taylor 2003). As such, country factors remain important in understanding the frequency of sudden stops. A previous study showing that the correlation between changes in U.S. Treasury yields and capital flows to emerging markets was not always stable (that the correlation depended on the reason behind the change in U.S. Treasury yields) is Eichengreen and Mody (1998).

24. As in Calvo, Izquierdo, and Mejia (2004), we also included a measure of dollarization. Confirming their finding, dollarization is associated with a higher probability of a sudden stop. However, our other findings do not change, and we do not include dollarization in the regressions to preserve the sample size. 
- We relaxed our stringent criteria and mechanical procedures for identifying sudden stop episodes, adding additional borderline cases such as Russia and Brazil at the end of the 1990s. Again, the results carried over. $^{25}$

- Using the Reinhart-Rogoff classification of exchange rate regimes, we added dummy variables for pegged rates and regimes of limited flexibility (managed- and freely-floating regimes are the omitted alternative). ${ }^{26} \mathrm{We}$ find (in table 7.8) that the more rigid the regime, the greater the likelihood of a sudden stop. ${ }^{27}$ This negative association of sudden stops with exchange rate flexibility is consistent with the literature in which it is argued that currency flexibility encourages creditors and debtors to more fully internalize the risks of foreign lending and borrowing (see, e.g., Goldstein 1998). This is also the same result as in Edwards (2005). While the vector of exchange rate regime variables is not significant here, it turns out to be significant in some of the additional specifications below. ${ }^{28}$

- Because exchange rate regime and capital account regime choices are related, we also considered the effects of financial opening. We use a one-period lag of the Mody and Murshid (2005) measure of financial integration. ${ }^{29}$ The point estimate (again in table 7.8) suggests that countries that are more deeply integrated with global financial markets are less vulnerable to sudden stops, as if countries better integrated into international financial markets have stronger institutions. Again, this is the same result as in Edwards (2005). And although this variable is also not significant here, it turns out to be significant in some of the further specifications in the following.

\subsection{IMF Programs and Sudden Stops}

Table 7.9 adds IMF programs. Recall that we distinguish "existing" programs (in place at least two years prior to the occurrence of the sudden stop) from "new" programs negotiated in the immediately preceding two years. The coefficient on preexisting programs is arguably less contaminated by simultaneity (which should in any case bias the coefficient in a positive direction, the opposite of the sign we find). Preexisting programs, as a mea-

25. Similarly, all the results reported in the following continue to obtain when we add these borderline cases to our list of sudden stop episodes.

26. See Reinhart and Rogoff (2004). In principle, it captures the de facto operative regime.

27. Although the effect is not statistically significant, it is found to be significant in the later tables.

28. Note, however, that the new IMF classification of exchange rates produces more ambiguous results.

29. The financial integration index is based on four measures of the intensity of capital controls that are published in the IMF's annual Report on Exchange Arrangements and Exchange Restrictions. 
Table 7.8

Financial mobility, exchange rate regimes, and sudden stops

\begin{tabular}{|c|c|c|c|c|}
\hline \multirow{3}{*}{$\frac{\text { Dependent variable }}{\text { High yield spread }}$} & \multicolumn{4}{|c|}{ Indicator for first year of sudden stop } \\
\hline & $0.012 *$ & $0.013^{*}$ & 0.011 & $0.012 *$ \\
\hline & {$[1.84]$} & {$[1.91]$} & {$[1.61]$} & {$[1.73]$} \\
\hline \multirow[t]{2}{*}{ Change in real oil prices } & $-0.002 * * *$ & $-0.002 * * *$ & $-0.002 * * *$ & $-0.002 * * *$ \\
\hline & {$[3.11]$} & {$[3.08]$} & {$[3.17]$} & {$[3.19]$} \\
\hline \multirow[t]{2}{*}{ GDP growth } & $0.007 * *$ & $0.007 * *$ & $0.007 *$ & $0.007 * *$ \\
\hline & {$[2.16]$} & {$[2.21]$} & {$[1.90]$} & {$[2.02]$} \\
\hline \multirow[t]{2}{*}{ Trade balance/GDP } & -0.006 & $-0.007 *$ & $-0.007 *$ & $-0.008 * *$ \\
\hline & {$[1.47]$} & {$[1.66]$} & {$[1.76]$} & {$[2.08]$} \\
\hline \multirow[t]{2}{*}{ Debt servicing/Exports } & $0.002 * *$ & $0.002 * *$ & $0.002 * *$ & $0.002 * *$ \\
\hline & {$[2.03]$} & {$[2.01]$} & {$[2.05]$} & {$[2.09]$} \\
\hline \multirow[t]{2}{*}{ Domestic credit/GDP } & $0.003^{* *}$ & $0.002 * *$ & $0.002 * *$ & $0.002 * *$ \\
\hline & {$[2.41]$} & {$[2.28]$} & {$[2.35]$} & {$[2.41]$} \\
\hline \multirow[t]{2}{*}{ Change in domestic credit/GDP } & $0.005^{* * *}$ & $0.005^{* * *}$ & $0.005^{* * *}$ & $0.005 * * *$ \\
\hline & {$[2.68]$} & {$[2.70]$} & {$[2.75]$} & {$[2.82]$} \\
\hline \multirow[t]{2}{*}{ Exchange rate regime: Pegged } & 0.028 & 0.033 & & \\
\hline & {$[0.54]$} & {$[0.61]$} & & \\
\hline \multirow[t]{2}{*}{ Exchange rate regime: Limited flexibility } & 0.03 & 0.03 & & \\
\hline & {$[0.69]$} & {$[0.53]$} & & \\
\hline \multirow[t]{2}{*}{ Exchange rate regime: Pegged (IMF) } & & & -0.03 & -0.04 \\
\hline & & & {$[1.15]$} & {$[1.27]$} \\
\hline \multirow[t]{2}{*}{ Exchange rate regime: Limited flexibility (IMF) } & & & 0.02 & 0.02 \\
\hline & & & {$[0.52]$} & {$[0.57]$} \\
\hline \multirow[t]{2}{*}{ Financial mobility } & & -0.01 & & -0.02 \\
\hline & & {$[0.75]$} & & {$[1.06]$} \\
\hline Country fixed effects & Yes & Yes & Yes & Yes \\
\hline Time fixed effects & No & No & No & No \\
\hline Pseudo $R^{2}$ & 0.21 & 0.21 & 0.21 & 0.21 \\
\hline No. of observations & 227 & 227 & 227 & 227 \\
\hline
\end{tabular}

Note: See table 7.7 notes.

***Significant at the 1 percent level.

**Significant at the 5 percent level.

*Significant at the 10 percent level.

sure of the IMF's ongoing commitment to the country, may also have a stronger signaling effect. In practice, we find that both preexisting and new programs negatively affect the probability of a sudden stop. In the present specification, the coefficient on new programs is larger in absolute value, although it does not differ significantly from that on existing programs. ${ }^{30}$

The insurance analogy is sometimes taken as an argument for exceptional access - as justifying a credit line sufficiently large to reassure private investors. This suggests distinguishing effects by the size of the program.

30. The size of the coefficients differs more noticeably when we correct for endogeneity, as suggested by the observation that preexisting programs should be less contaminated by this bias (see the following). 
IMF program and probability of sudden stops (probit estimates)

\begin{tabular}{|c|c|c|c|c|c|}
\hline \multirow{3}{*}{$\begin{array}{l}\text { Dependent variable } \\
\text { High yield spread }\end{array}$} & \multicolumn{5}{|c|}{ Indicator for first year of sudden stop } \\
\hline & $0.011^{*}$ & $0.011 * *$ & $0.011 *$ & $0.012 * *$ & 0.006 \\
\hline & {$[1.81]$} & {$[1.98]$} & {$[1.94]$} & {$[2.04]$} & {$[1.03]$} \\
\hline \multirow[t]{2}{*}{ Change in real oil prices } & $-0.001 * * *$ & $-0.001 * * *$ & $-0.001 * * *$ & $-0.001 * * *$ & $-0.001 * * *$ \\
\hline & {$[3.15]$} & {$[3.19]$} & {$[3.18]$} & {$[3.10]$} & [3.69] \\
\hline \multirow[t]{2}{*}{ GDP growth } & $0.006^{*}$ & $0.007 * *$ & $0.007 *$ & $0.007 * *$ & $0.009 * * *$ \\
\hline & {$[1.73]$} & {$[2.00]$} & {$[1.93]$} & {$[2.11]$} & {$[2.66]$} \\
\hline \multirow[t]{2}{*}{ Trade balance/GDP } & -0.005 & -0.002 & -0.002 & -0.003 & -0.003 \\
\hline & {$[1.37]$} & {$[0.63]$} & {$[0.62]$} & {$[0.96]$} & {$[0.99]$} \\
\hline \multirow[t]{2}{*}{ Debt servicing/Exports } & $0.002 * *$ & $0.002 * * *$ & $0.002 * * *$ & $0.002 * *$ & 0.001 \\
\hline & [2.29] & [2.69] & {$[2.70]$} & {$[2.46]$} & [1.49] \\
\hline \multirow[t]{2}{*}{ Domestic credit/GDP } & $0.002 * * *$ & $0.003^{* * *}$ & $0.003^{* * *}$ & $0.003 * * *$ & $0.002 * * *$ \\
\hline & {$[2.66]$} & {$[3.08]$} & {$[3.06]$} & {$[3.02]$} & {$[2.95]$} \\
\hline \multirow[t]{2}{*}{ Change in domestic credit/GDP } & $0.004 * * *$ & $0.003 * *$ & $0.003 * *$ & $0.004 * * *$ & $0.004 * * *$ \\
\hline & {$[2.63]$} & {$[2.53]$} & {$[2.49]$} & {$[2.59]$} & {$[3.18]$} \\
\hline \multirow[t]{2}{*}{ Exchange rate regime: Pegged } & 0.067 & 0.07 & 0.071 & 0.069 & 0.022 \\
\hline & {$[1.14]$} & {$[1.23]$} & {$[1.24]$} & {$[1.20]$} & {$[0.53]$} \\
\hline \multirow[t]{2}{*}{ Exchange rate regime: Limited flexibility } & 0.007 & -0.006 & -0.005 & -0.006 & -0.003 \\
\hline & {$[0.20]$} & {$[0.20]$} & {$[0.16]$} & {$[0.19]$} & {$[0.11]$} \\
\hline \multirow[t]{2}{*}{ Financial mobility } & -0.018 & -0.017 & -0.016 & -0.017 & -0.016 \\
\hline & {$[1.45]$} & {$[1.59]$} & {$[1.40]$} & {$[1.52]$} & {$[1.51]$} \\
\hline \multirow[t]{2}{*}{ Existing IMF program } & $-0.054 * * *$ & $-0.046^{* *}$ & $-0.046^{* *}$ & $-0.049 * *$ & $-0.043^{* *}$ \\
\hline & {$[2.98]$} & {$[2.57]$} & {$[2.56]$} & {$[2.56]$} & {$[2.47]$} \\
\hline \multirow[t]{2}{*}{ New IMF program } & $-0.053^{* * *}$ & $-0.042 *$ & -0.041 & $-0.047^{*}$ & -0.040 \\
\hline & [1.99] & [1.73] & {$[1.63]$} & {$[1.81]$} & {$[1.64]$} \\
\hline \multirow[t]{2}{*}{ New program $\cdot$ Fundamentals } & & & & & $0.046^{* *}$ \\
\hline & & & & & {$[2.32]$} \\
\hline \multirow[t]{2}{*}{ Precautionary IMF program } & -0.014 & & -0.01 & & \\
\hline & {$[0.51]$} & & {$[0.38]$} & & \\
\hline \multirow[t]{2}{*}{ IMF credit/GDP } & & $-0.008 *$ & $-0.008^{*}$ & & \\
\hline & & {$[1.66]$} & {$[1.66]$} & & \\
\hline \multirow[t]{2}{*}{ IMF credit/Short-term debt } & & & & -.0001 & -.0001 \\
\hline & & & & {$[0.63]$} & {$[0.84]$} \\
\hline Country fixed effects & Yes & Yes & Yes & Yes & Yes \\
\hline Time fixed effects & No & No & No & No & No \\
\hline Pseudo $R^{2}$ & 0.26 & 0.28 & 0.28 & 0.27 & 0.30 \\
\hline No. of observations & 227 & 217 & 217 & 217 & 217 \\
\hline
\end{tabular}

Note: See table 7.7 notes.

***Significant at the 1 percent level.

**Significant at the 5 percent level.

*Significant at the 10 percent level.

We do so in two ways, scaling programs by short-term external debt and GDP. Both ratios are lagged by one period. International Monetary Fund credit as a share of GDP is negative and significant at conventional confidence levels, but not so IMF credit scaled by short-term debt.

Next we test for whether IMF programs have a more powerful preemp- 
tive effect in countries with strong fundamentals, as suggested by the insurance analogy. We construct the first principal component of the vector of variables capturing country policies and conditions included in table 7.9. ${ }^{31}$ We normalize the resulting variable so that it has zero mean and so that a positive value indicates worsening fundamentals. We then interact the resulting index of fundamentals with the new IMF program variable. The positive and significant coefficient on the interaction term in table 7.9 suggests that as the strength of domestic fundamentals declines, the effectiveness of IMF programs in reducing the likelihood of a sudden stop diminishes. $^{32}$

A key question is whether the negative association of programs and sudden stops reflects causality running from the latter to the former. Actually, it is not clear that endogeneity is a serious problem; one can argue that reverse causality should bias the coefficient toward zero because a sudden stop will increase the likelihood of a Fund program and thus produce a positive relationship, whereas we find a negative coefficient. ${ }^{33}$ Be that as it may, the appropriate treatment is instrumental variables. These authors argue that decision making in the Fund is influenced by the organization's principal shareholders, above all the United States. They model the likelihood of a program as a function not just of country characteristics but also of its links with the United States. ${ }^{34}$ To capture the latter they include U.S. aid as a percentage of total foreign aid received by the country and the share of votes in the United Nations (UN) General Assembly in which the country voted the same way as the United States, both lagged. ${ }^{35}$ In our sample, U.S.

31. We use high-yield spreads, oil prices, real GDP growth, the trade balance-GDP ratio, the debt service-export ratio, and the domestic credit measure in calculating principal components. The first principal component captures 21 percent of the variation in the underlying series. In theory it would be possible to interact the IMF program dummy with each of the variables used to represent fundamentals (or to include additional principal components beyond the first), but this creates problems of multicollinearity and complicates interpretation. We could also construct our own linear combination of the variables representing fundamentals, but it seems preferable to let this simple statistical methodology do so for us.

32. This is a congenial finding for those who advance the insurance analogy for IMF programs. In earlier work analyzing the catalytic effect of the IMF on capital flows, we find similar evidence of threshold effects, especially for access to bond markets (Mody and Saravia 2003; Eichengreen, Kletzer, and Mody 2006). In particular, countries in an intermediate state of vulnerability seemed to benefit from improved market access, while others did not.

33. We provide some evidence on this in the following.

34. Dreher and Jensen (2003) take a similar empirical approach but take as their dependent variable the number of conditions attached to a program. Oatley and Yackee (2004) consider instead the political determinants of the size of IMF loans.

35. The authors also use past participation in Fund programs as an instrument. The problem with using lags of the endogenous variable as an instrument is, of course, that they may be picking up omitted country characteristics that are slow to change and durably associated with financial problems; see Mody and Stone (2005). Alternatively, we can follow Celasun and Ramcharan (2005) by using the share of G3 exports going to each subject country as a measure of the importance the principal shareholders may attach to extending assistance through the Fund. However this variable turns out to be a poor instrument for the incidence of the 
aid enters the first-stage regression positively, as predicted, and is significantly different from zero. ${ }^{36}$ United Nations voting patterns, in contrast, do not exhibit the expected sign. ${ }^{37}$ Given the counterintuitive sign on this variable, we rely on the specification in the first column of table 7.10, which excludes UN voting patterns, for purposes of instrumentation. ${ }^{38}$

Table 7.11 shows the second-stage estimates. The presence of a new IMF program continues to negatively influence the probability of a sudden stop. Both the statistical significance and absolute value of the coefficient are greater than before. This is to be expected: if susceptibility to a sudden stop increases the likelihood of an IMF program, then reverse causality will bias the coefficient in a positive direction; correcting for simultaneity thus yields a more significant negative coefficient whose absolute value is larger. Preexisting programs are significant as well. All this is consistent with the hypothesis that IMF programs provide valuable insurance against sudden stops.

Given the strong policy implications of these findings, we considered a number of further robustness checks.

- When we consider the longer period starting in 1984, as in the last column of table 7.11 , the strength of preexisting programs remains. In contrast, the coefficient on new programs becomes less significant. It would thus appear that the signaling effect of an ongoing IMF commitment to the country is particularly important in the more recent period. The interaction between new programs and fundamentals remains unchanged even in the longer period, pointing to continued importance of country fundamentals in determining the influence of IMF programs.

IMF program. The coefficient of this variable is consistently negative and significant in the first stage regressions of IMF programs. One interpretation is that it is a proxy for the size of the country, and the larger countries are probably less susceptible to problems necessitating an IMF program.

36. Use of voting in the UN General Assembly has been criticized in the political science literature for being dominated by nonconsequential votes and thus containing relatively little information on political affinity. This is one interpretation of what we find in the first-stage regressions.

37. Note that we include also a number of addition global and country-specific variables that may influence the decision to approach the Fund (and the Fund's decision to extend assistance). While these variables do not provide identification in the second stage (they do not plausibly satisfy the exclusion criterion for an instrumental variable), they reassure us that any significance we impute to the U.S. aid in the first stage is really attributable to these other characteristics.

38. Of interest also in the determinants of IMF programs are the similarities and contrasts with the determinants of sudden stops. External debt and debt service indicators work in the same way (though with differing strengths): more debt and debt service increase the likelihood of both IMF programs and of sudden stops. In contrast, domestic growth based on high and growing levels of credit are associated with a lower likelihood of IMF programs. Thus, countries experiencing such exuberant growth are unlikely to contract with the IMF and remain susceptible to sudden stops. 
Table 7.10

Determinants of IMF programs

\begin{tabular}{|c|c|c|c|c|c|c|}
\hline \multirow{2}{*}{$\begin{array}{l}\text { Dependent variable } \\
\text { U.S. aid }\end{array}$} & \multicolumn{6}{|c|}{ New IMF program in $\mathrm{T}-1$ or $\mathrm{T}-2$} \\
\hline & $0.058 * * *$ & $0.078^{* * *}$ & $0.072 * * *$ & $0.079 * * *$ & $0.071^{* * *}$ & $0.080 * * *$ \\
\hline & {$[3.79]$} & {$[3.09]$} & {$[3.24]$} & {$[3.15]$} & {$[3.16]$} & {$[3.15]$} \\
\hline \multirow[t]{2}{*}{ Real growth } & -0.011 & $-0.027 * *$ & $-0.018^{*}$ & $-0.027^{* *}$ & $-0.018^{*}$ & $-0.028 * *$ \\
\hline & {$[1.53]$} & {$[2.56]$} & {$[1.76]$} & {$[2.51]$} & {$[1.68]$} & [2.47] \\
\hline \multirow[t]{2}{*}{ Trade balance/GDP } & $0.024 * * *$ & $0.047 * * *$ & $0.038 * * *$ & $0.046^{* * *}$ & $0.042 * * *$ & $0.046^{* * *}$ \\
\hline & {$[3.49]$} & {$[3.95]$} & {$[3.15]$} & {$[3.69]$} & {$[3.52]$} & {$[3.69]$} \\
\hline \multirow[t]{2}{*}{ Debt servicing/Exports } & $0.008 * * *$ & $0.009 * *$ & $0.008 * *$ & $0.009^{* *}$ & $0.009^{* *}$ & $0.009 * *$ \\
\hline & {$[2.95]$} & {$[2.36]$} & {$[2.11]$} & {$[2.37]$} & {$[2.06]$} & {$[2.23]$} \\
\hline \multirow[t]{2}{*}{ Domestic credit/GDP } & $-0.004^{*}$ & $-0.006^{*}$ & -0.006 & $-0.006^{*}$ & -0.005 & $-0.006^{*}$ \\
\hline & [1.83] & [1.68] & {$[1.62]$} & {$[1.71]$} & {$[1.54]$} & {$[1.74]$} \\
\hline \multirow[t]{2}{*}{ Change in domestic credit/GDP } & $-0.007 *$ & -0.006 & -0.008 & -0.007 & -0.007 & -0.007 \\
\hline & {$[1.79]$} & {$[1.23]$} & {$[1.38]$} & {$[1.35]$} & {$[1.25]$} & {$[1.37]$} \\
\hline \multirow[t]{2}{*}{ Debt/GDP } & $0.007 * * *$ & $0.009^{* * *}$ & $0.01^{* * *}$ & $0.01 * * *$ & $0.01 * * *$ & $0.01 * * *$ \\
\hline & {$[3.84]$} & {$[3.49]$} & {$[3.73]$} & {$[3.70]$} & {$[3.55]$} & {$[3.64]$} \\
\hline \multirow[t]{2}{*}{ Change in debt } & 0.002 & $0.007 *$ & $0.009^{* *}$ & $0.008^{*}$ & $0.009^{* *}$ & 0.008 \\
\hline & {$[0.57]$} & {$[1.76]$} & {$[2.29]$} & {$[1.88]$} & {$[2.14]$} & [1.89] \\
\hline \multirow[t]{2}{*}{ Reserves/Imports } & 0.001 & -0.001 & 0.001 & 0.001 & 0.001 & 0.0003 \\
\hline & {$[0.63]$} & {$[0.10]$} & {$[0.53]$} & {$[0.19]$} & {$[0.21]$} & {$[0.13]$} \\
\hline \multirow[t]{2}{*}{ Short-term Debt/Reserves } & $-0.001 * * *$ & $-0.001 * * *$ & $-0.001 * * *$ & $-0.001 * * *$ & $-0.001 * * *$ & $-0.001 * * *$ \\
\hline & {$[2.68]$} & {$[2.76]$} & {$[2.63]$} & {$[2.82]$} & {$[2.58]$} & {$[2.77]$} \\
\hline \multirow[t]{2}{*}{ Exchange rate regime: Pegged } & $0.28^{* * *}$ & $0.45^{* *}$ & $0.37^{*}$ & $0.46^{* *}$ & $0.40^{* *}$ & $0.47^{* *}$ \\
\hline & [2.69] & {$[2.29]$} & {$[1.86]$} & {$[2.21]$} & {$[2.29]$} & {$[2.27]$} \\
\hline \multirow{2}{*}{$\begin{array}{l}\text { Exchange rate regime: } \\
\text { Limited flexibility }\end{array}$} & -0.006 & -0.035 & -0.103 & -0.071 & -0.052 & -0.067 \\
\hline & {$[0.08]$} & {$[0.27]$} & {$[0.75]$} & {$[0.48]$} & {$[0.41]$} & {$[0.46]$} \\
\hline \multirow[t]{2}{*}{ UN voting } & & $-0.045^{* * *}$ & & $-0.046^{* * *}$ & & $-0.046^{* * *}$ \\
\hline & & {$[2.92]$} & & {$[3.00]$} & & {$[2.95]$} \\
\hline \multirow[t]{2}{*}{ Exposure of U.S. banks } & & & & & -0.004 & -0.011 \\
\hline & & & & & {$[0.18]$} & {$[0.51]$} \\
\hline \multirow[t]{2}{*}{ Exports by $\mathrm{G} 3$ countries } & & & 0.017 & 0.076 & & 0.067 \\
\hline & & & {$[0.14]$} & {$[0.60]$} & & {$[0.53]$} \\
\hline Country fixed effects & Yes & Yes & Yes & Yes & Yes & Yes \\
\hline Time fixed effects & Yes & Yes & Yes & Yes & Yes & Yes \\
\hline Pseudo $R^{2}$ & 0.27 & 0.36 & 0.32 & 0.37 & 0.26 & 0.37 \\
\hline No. of observations & 379 & 284 & 302 & 283 & 303 & 283 \\
\hline
\end{tabular}

Note: See table 7.7 notes.

***Significant at the 1 percent level.

**Significant at the 5 percent level.

*Significant at the 10 percent level.

- As in the preceding, we analyzed whether our results held up when we relaxed the stringent criteria used to identify sudden stops. First, we added Brazil and Russia in 1999, two cases that many would regard as sudden stops but which are not picked up by our criteria. Second, we dropped Bangladesh, Bolivia, Ghana, and Pakistan, which drew on the Fund's concessional financing facilities, indicating that their 


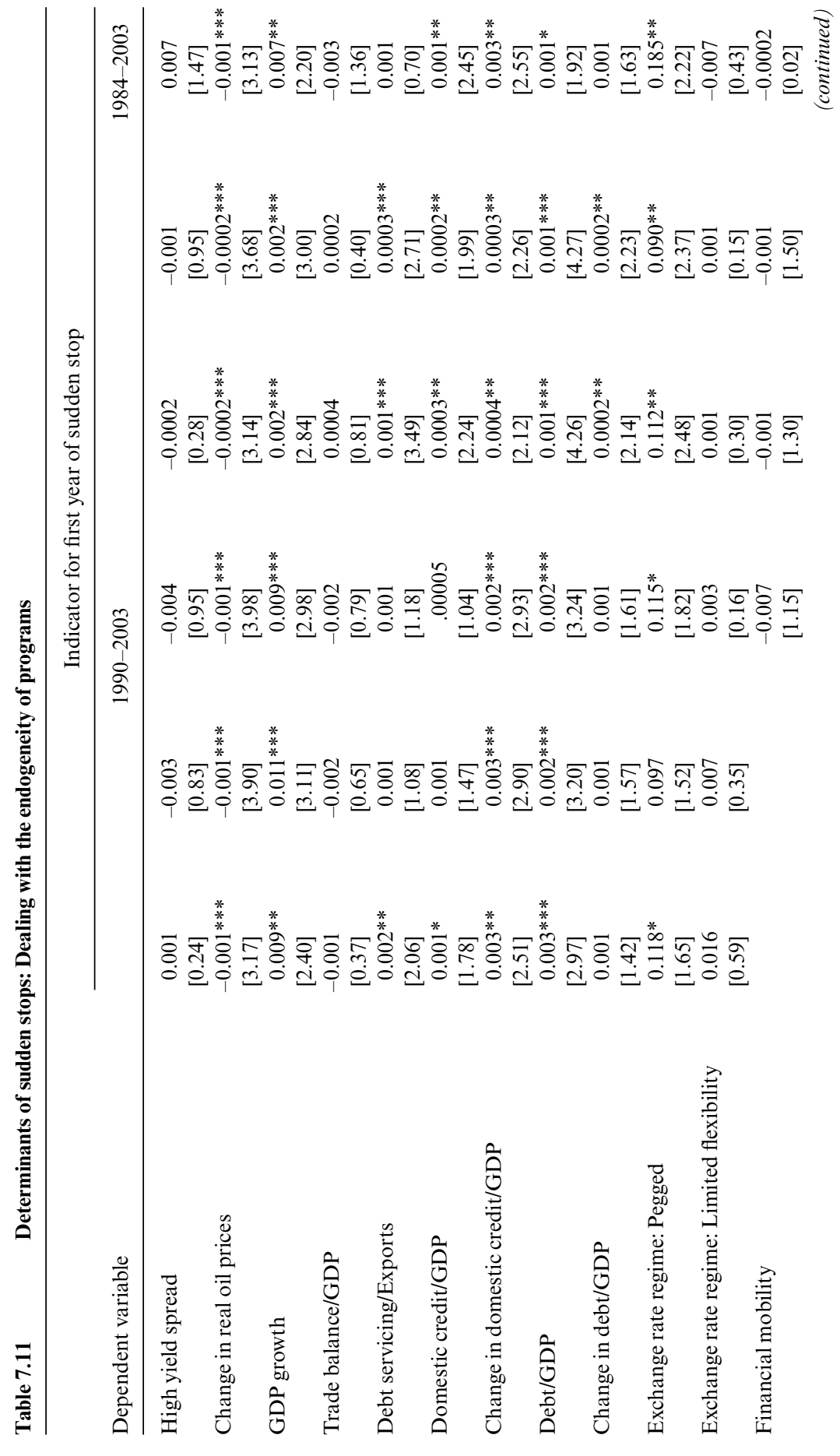




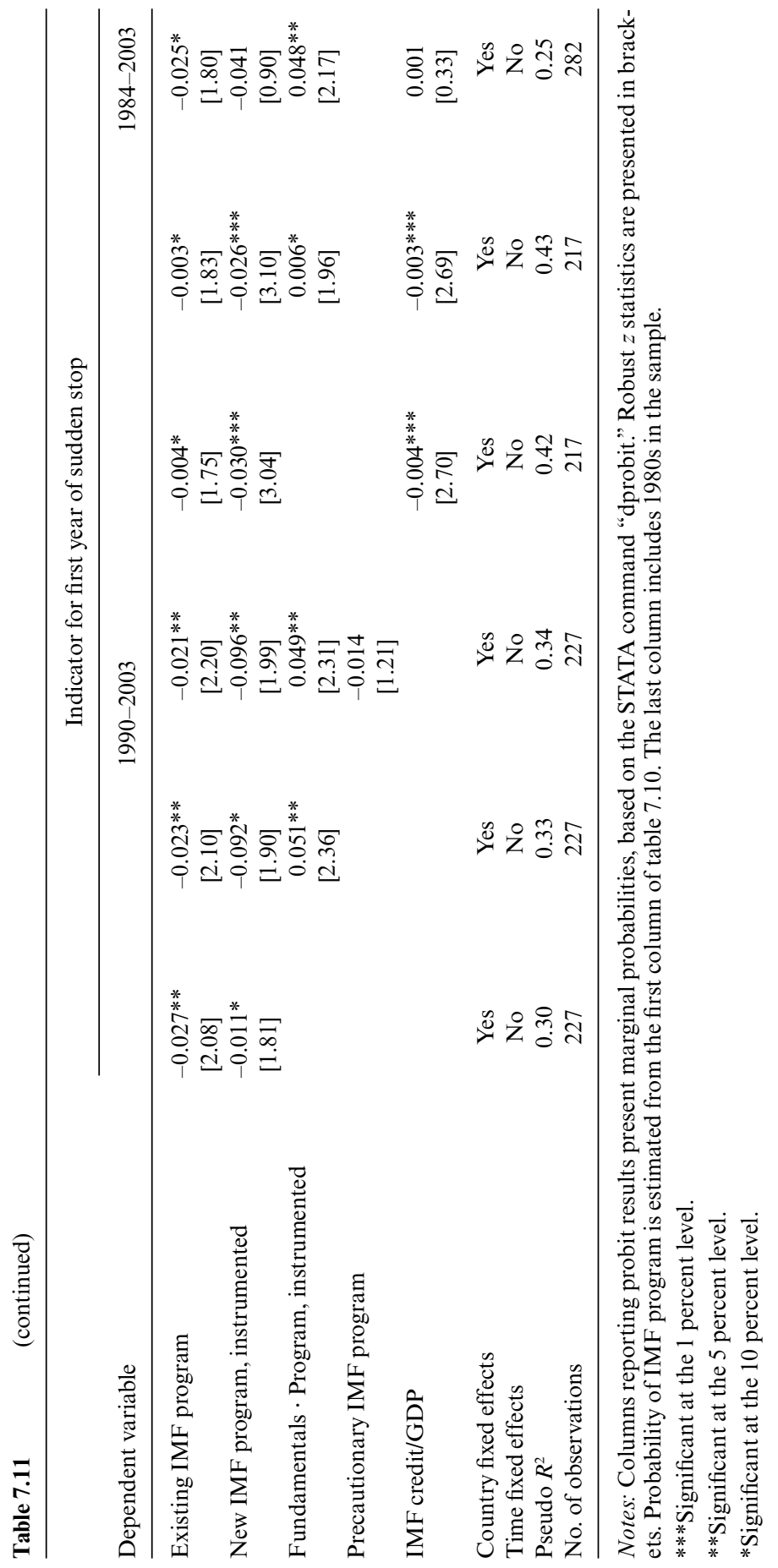


international capital market linkages were qualitatively different from those of the other country samples. The results remained the same. ${ }^{39}$

- We considered alternative instrumentation strategies. For example, following Oatley and Yackee (2004), we constructed a measure of country indebtedness to U.S. banks as a further instrument. Adding it has relatively little impact on the results (perhaps because this variable turns out to be a relatively weak instrument in this context).

\subsection{Extensions}

We also asked whether IMF programs reduce the intensity (as opposed to the frequency) of sudden stops. For this purpose we constructed our dependent variable as the financial account outflow if and only if a sudden stop occurs. Regressions using this dependent variable are estimated by tobit.

The results, in table 7.12, are similar to the earlier probit estimates, though with some noteworthy differences. There is stronger evidence for an increase in high-yield spreads, reflecting a rise in risk aversion, to be associated with a reduction in capital inflows. As before, a rise in oil prices works in the opposite direction. Among country factors, a high credit-toGDP ratio and rapid credit growth are associated with larger capital outflows, and a more open capital account regime appears to reduce the intensity of a sudden stop. ${ }^{40}$ Compared to new programs, preexisting programs seem to have a clearer effect in reducing the intensity of capital outflows; also while new programs and their interaction with fundamentals work in the same way as before, the statistical significance is weaker. Note that when new programs are instrumented, the size of the coefficient again becomes noticeably, even implausibly, large in absolute-value terms. Finally, when all the relevant IMF variables are included, as in the last two columns of table 7.12, the precision of the estimates declines.

We also considered the impact of IMF programs on growth around the time of sudden stops. The raw data in the second panel of table 7.13 suggest the recessionary impact of sudden stops in countries both with and without Fund programs. Growth is even slower following sudden stops in those cases where IMF programs are present. But the financial balance (in the first panel of table 7.13) is also worse when a Fund program is present - suggesting, plausibly, that programs are put in place in cases where economic circumstances are worse-reminds us that other things are not in fact equal, and the slower growth cannot be attributed to IMF programs without further investigation.

39. In fact, dropping the country with concessional financing strengths the results, pointing especially to the risks to the others of pegging exchange rates and indicating greater value to a more open capital account (see appendix A, 7A.1 and 7A.2).

40. Other conditioning variables are less significant, though virtually always of the same sign as in the probit estimates. 
Table 7.12

IMF programs and intensity of sudden stops

\begin{tabular}{|c|c|c|c|c|c|}
\hline \multirow{3}{*}{$\frac{\text { Dependent variable }}{\text { High yield spread }}$} & \multicolumn{5}{|c|}{ Financial account outflow if a sudden stop occurred } \\
\hline & $1.38^{* *}$ & $1.35^{* *}$ & 0.49 & $1.23^{*}$ & 0.73 \\
\hline & {$[2.17]$} & {$[2.12]$} & {$[0.73]$} & {$[1.74]$} & {$[1.00]$} \\
\hline \multirow[t]{2}{*}{ Change in real oil prices } & $-0.11^{*}$ & $-0.11^{*}$ & $-0.16^{* *}$ & $-0.12^{*}$ & $-0.15^{* *}$ \\
\hline & {$[1.86]$} & {$[1.87]$} & {$[2.32]$} & {$[1.93]$} & {$[2.20]$} \\
\hline \multirow[t]{2}{*}{ GDP growth } & 0.61 & 0.58 & $0.97^{*}$ & 0.67 & $1.04 *$ \\
\hline & {$[1.30]$} & {$[1.24]$} & {$[1.72]$} & {$[1.26]$} & {$[1.71]$} \\
\hline \multirow[t]{2}{*}{ Trade balance/GDP } & -0.35 & -0.35 & -0.32 & 0.20 & 0.17 \\
\hline & [0.89] & {$[0.88]$} & {$[0.74]$} & {$[0.41]$} & {$[0.34]$} \\
\hline \multirow[t]{2}{*}{ Debt servicing/Exports } & $0.23^{* *}$ & $0.23^{* *}$ & 0.16 & $0.38^{* *}$ & $0.29 *$ \\
\hline & {$[2.16]$} & {$[2.19]$} & {$[1.21]$} & {$[2.50]$} & {$[1.80]$} \\
\hline \multirow[t]{2}{*}{ Domestic credit/GDP } & $0.20^{*}$ & $0.19^{*}$ & 0.09 & $0.21 *$ & 0.16 \\
\hline & {$[1.81]$} & {$[1.79]$} & {$[0.74]$} & {$[1.67]$} & {$[1.23]$} \\
\hline \multirow[t]{2}{*}{ Change in domestic credit/GDP } & $0.53^{* * *}$ & $0.52^{* * *}$ & $0.59 * * *$ & $0.51^{* * *}$ & $0.58^{* * *}$ \\
\hline & {$[3.35]$} & {$[3.30]$} & {$[3.41]$} & {$[3.08]$} & {$[3.27]$} \\
\hline \multirow[t]{2}{*}{ Exchange rate regime: Pegged } & 1.94 & 1.96 & 3.16 & 6.28 & 5.69 \\
\hline & {$[0.37]$} & {$[0.38]$} & {$[0.50]$} & {$[1.00]$} & {$[0.88]$} \\
\hline \multirow[t]{2}{*}{ Exchange rate regime: Limited flexibility } & 2.47 & 2.56 & 2.90 & 3.06 & 3.34 \\
\hline & {$[0.54]$} & {$[0.56]$} & {$[0.63]$} & {$[0.59]$} & {$[0.67]$} \\
\hline \multirow[t]{2}{*}{ Financial mobility } & $-2.73^{*}$ & $-2.57^{*}$ & $-3.23^{* *}$ & $-3.48 * *$ & $-3.62 * *$ \\
\hline & {$[1.85]$} & {$[1.70]$} & [1.99] & {$[2.06]$} & {$[2.09]$} \\
\hline \multirow[t]{2}{*}{ Existing IMF program } & $-7.98 * *$ & $-7.79 * *$ & -5.44 & -6.48 & -5.04 \\
\hline & {$[2.03]$} & [1.99] & {$[1.62]$} & {$[1.54]$} & {$[1.46]$} \\
\hline \multirow[t]{2}{*}{ New IMF program } & -4.75 & -4.54 & & & \\
\hline & {$[1.60]$} & {$[1.52]$} & & & \\
\hline \multirow[t]{2}{*}{ New IMF program, instrumented } & & & -16.94 & -12.60 & -18.18 \\
\hline & & & [1.56] & {$[1.16]$} & [1.58] \\
\hline \multirow[t]{2}{*}{ Fundamentals $\cdot$ Program, instrumented } & & & $7.80^{*}$ & & 6.01 \\
\hline & & & {$[1.69]$} & & {$[1.27]$} \\
\hline \multirow[t]{2}{*}{ Precautionary IMF program } & & -2.32 & & & \\
\hline & & {$[0.37]$} & & & \\
\hline \multirow[t]{2}{*}{ IMF credit/GDP } & & & & -1.23 & -1.35 \\
\hline & & & & {$[1.30]$} & {$[1.43]$} \\
\hline Country fixed effects & Yes & Yes & Yes & Yes & Yes \\
\hline Time fixed effects & No & No & No & No & No \\
\hline Pseudo $R^{2}$ & 0.18 & 0.18 & 0.19 & 0.20 & 0.21 \\
\hline No. of observations & 227 & 227 & 227 & 217 & 217 \\
\hline
\end{tabular}

Note: These estimations are based on the "tobit" procedure, with a cut-off at zero outflows.

$* * *$ Significant at the 1 percent level.

**Significant at the 5 percent level.

*Significant at the 10 percent level.

It turns out to be difficult to draw firm conclusions about the impact on output of IMF programs in these episodes. As a first cut, we regressed annual growth (again in a country panel covering the period 1990-2003) on a vector of controls, the presence or absence of a sudden stop, a dummy variable for the presence of a Fund program, and the interaction of the sudden 


\begin{tabular}{cccc}
\hline & \multicolumn{2}{c}{ Sudden Stop } & \\
\cline { 2 - 3 } Program & No & Yes & Total \\
\hline \multirow{4}{*}{ No } & Financial account balance & $(\%$ of GDP $)$ & \\
Yes & 3.05 & -2.73 & 2.46 \\
Total & 2.23 & -6.56 & 1.61 \\
& 2.7 & -4.01 & 2.1 \\
No & \multicolumn{2}{c}{ Real growth } & \\
Yes & 4.18 & 0.68 & 3.82 \\
Total & 2.54 & -2.5 & 2.19 \\
& 3.48 & -0.38 & 3.14 \\
\hline
\end{tabular}

stop and the presence of a program (table 7.14). In the benchmark regression in the first column, per capita income in the previous year enters negatively and significantly, suggesting some short-term mean reversion. More rapid U.S. growth is conducive to more rapid recovery in emerging market countries. A sudden stop leads to slower growth, as expected. The dummy for the presence of a Fund program is negative and significant, with two alternative interpretations: the strict conditionality generally associated with programs leads to slower growth in the short run or that programs are associated with weak fundamentals not included in the regression.

Importantly for present purposes, the interaction between the IMF programs and sudden stops is not significant. In other words, even if Fund programs reduce the incidence of sudden stops, they do not obviously shape their impact on growth in one direction or the other. We find the same basic results on adding additional financial controls in columns (2) and (3) of table 7.14.

We know from earlier sections that countries with IMF programs are not randomly selected from the larger population. Before drawing conclusions about their impact on growth, we therefore need to control not just for observed differences between program and nonprogram countries but also for unobserved heterogeneity. In columns (4) to (5) we use the twostage Heckman procedure, adding as an additional regressor the Inverse Mills ratio, denoted Lambda, derived from the first-stage regression of the determinants of IMF programs (in the first column of table 7.10) ${ }^{41}$ Sudden stops continue to exert a negative impact on growth (significant in column [4], insignificant in column [5], where the financial balance is introduced directly). IMF programs now have a positive rather than a negative impact

41. Dropping the interaction term allows us to estimate the same relationship using STATA's more efficient Heckman procedure (where the selection and growth equations are estimated simultaneously). In the present instance, results using the two estimation procedures are virtually indistinguishable. 
Table 7.14 Growth regressions: Effects of sudden stops and IMF programs

\begin{tabular}{lccccc}
\hline & \multicolumn{5}{c}{ GDP growth } \\
\cline { 2 - 6 } Dependent variable & $(1)$ & $(2)$ & $(3)$ & $(4)$ & $(5)$ \\
\hline GDP growth, lagged & $0.003^{* * *}$ & $0.002^{* *}$ & 0.001 & $0.002^{* *}$ & $0.001^{*}$ \\
& {$[4.88]$} & {$[2.60]$} & {$[1.62]$} & {$[2.57]$} & {$[1.93]$} \\
Per capita income, lagged & $-0.064^{* * *}$ & $-0.066^{* * *}$ & $-0.057^{* * *}$ & $-0.062^{* * *}$ & $-0.050^{* * *}$ \\
& {$[4.90]$} & {$[3.90]$} & {$[3.48]$} & {$[3.64]$} & {$[3.02]$} \\
Sudden stop & $-0.041^{* * *}$ & $-0.027^{* * *}$ & -0.015 & $-0.025^{* * *}$ & -0.011 \\
& {$[3.88]$} & {$[2.94]$} & {$[1.63]$} & {$[2.72]$} & {$[1.22]$} \\
IMF program & $-0.013^{* *}$ & $-0.009^{*}$ & $-0.010^{* *}$ & 0.007 & 0.016 \\
& {$[2.31]$} & {$[1.88]$} & {$[2.10]$} & {$[0.55]$} & {$[1.24]$} \\
Sudden stop · IMF program & 0.002 & -0.004 & 0.003 & -0.006 & 0.002 \\
& {$[0.09]$} & {$[0.25]$} & {$[0.20]$} & {$[0.40]$} & {$[0.11]$} \\
Debt/GDP & & $-0.001^{* * *}$ & $-0.001^{* * *}$ & $-0.001^{* * *}$ & $-0.001^{* * *}$ \\
& & {$[4.18]$} & {$[2.75]$} & {$[4.56]$} & {$[3.28]$} \\
Change in debt/GDP & & $-0.001^{* * *}$ & $-0.001^{* * *}$ & $-0.002^{* * *}$ & $-0.001^{* * *}$ \\
& & {$[7.78]$} & {$[6.37]$} & {$[8.51]$} & {$[7.27]$} \\
Debt service/Exports & & 0.0001 & -0.0002 & -0.0001 & -0.0003 \\
& & {$[0.81]$} & {$[0.12]$} & {$[0.29]$} & {$[1.28]$} \\
Financial balance/GDP & & & $0.002^{* * *}$ & & $0.003^{* * *}$ \\
& & & $4.14]$ & & {$[4.42]$} \\
Lambda & & & & -0.01 & $-0.016^{* *}$ \\
& & & & {$[1.28]$} & {$[2.11]$} \\
Country fixed effects & & Yes & Yes & Yes & Yes \\
Time fixed effects & Yes & Yes & Yes & Yes & Yes \\
No. of observations & Yes & 230 & 230 & 227 & 227 \\
No. of countries & 238 & 17 & 17 & 17 & 17 \\
$R^{2}$ & 0.32 & 0.51 & 0.55 & 0.54 & 0.58 \\
\hline
\end{tabular}

Notes: Robust $t$-statistics are presented in brackets. Columns (4) and (5) were estimated to allow for the possibility of selection bias on account of countries selecting themselves into IMF programs because they expect slow growth. The two-step "heckman" procedure was used. A first-stage selection equation estimated the probability of an IMF program (using the specification in table 7.10, column 1) and the estimated inverse-Mills ratio was added to the determinants of growth.

$* * *$ Significant at the 1 percent level.

** Significant at the 5 percent level.

*Significant at the 10 percent level.

on growth (though with weak statistical significance). The change in sign is consistent with the negative coefficient on the Inverse Mills ratio, which implies that unobserved country-specific factors that raise the likelihood of an IMF program also reduce the country's growth rate. But the $t$ statistics leave us reluctant to push any conclusion about this too far. The key finding remains: the interaction of sudden stops and IMF programs is still indistinguishable from zero. Thus, while the presence of a program may reduce the incidence of sudden stops, there is no evidence that pro- 
grams affect short-term output losses, one way or the other, when sudden stops do occur.

\subsection{Conclusions and Implications}

In this paper we have presented a first attempt to identify the impact of IMF programs on sudden stops. The literature on self-fulfilling crises and the insurance motive for IMF lending suggests that Fund programs could reduce the incidence of these episodes characterized by disruptive capitalflow reversals. In contrast, a literature critical of IMF programs suggests that such programs, especially those negotiated in the Asian crisis, have tended to be too small or too late and too laden with burdensome economic and political conditions to restore confidence..$^{42}$

Much of the evidence invoked in this debate is, however, anecdotal. A more systematic analysis such as that we have sought to provide here is clearly needed. Our results are broadly consistent with the notion that IMF programs have some effect in reducing the incidence of sudden stops. The evidence that negotiation of a Fund program in immediately prior years reduces the likelihood of a sudden stop is relatively robust. As economic logic suggests, this finding is, if anything, strengthened when we correct for endogeneity. The results further suggest that this effect operates more powerfully in countries with strong fundamentals, consistent with the insurance argument.

One should be cautious with these findings. The literature on the effects of IMF programs is notorious for its methodological limitations. Countries approaching the Fund differ systematically from other countries, creating problems of endogeneity and selectivity. In this paper we have described some instrumental-variables strategies and statistical adjustments for these problems. However, these approaches have limitations, and many of the same critiques levied against the related literature apply to the results reported here. These are more reasons for regarding the results as a first cut and not a definitive guide to policy.

Even if one accepts that there is evidence that IMF programs reduce the incidence and virulence of sudden stops, this leaves open the question of whether and how the institution's lending practices should be adapted. One view would be that such findings strengthen the case for a generously en-

42. Experience during the Asian crisis does not, of course, negate our findings on the insurance value of IMF programs, as when we limit the sample to the 1990s and after we find that preexisting programs were most effective, and in fact programs were not already in place in the countries with the most severe crises. Thus, in the case of Thailand, it can be argued that the problem was the absence of a program prior to the sudden stop-and that by the time an arrangement was negotiated, things had gotten out of hand. In contrast, the Philippines, which did have a program in place, experienced a milder sudden stop. 
dowed, quick disbursing, automatic facility for which countries with strong policies would presumably be prequalified. A different view would be that prequalification is impractical and automaticity is infeasible but that the Fund can still streamline and enhance access to its resources for countries with strong fundamentals. ${ }^{43}$ The results in this paper will not resolve this debate, but they will be more grist for the mill.

\section{Appendix A}

\section{Sudden Stop Dates and Sensitivity of Results to Sudden Stop Sample}

As described in the main text, a sudden stop is defined as occurring both when the financial balance is negative, that is there is a capital outflow, and there is a sharp increase in the capital outflow, measured by an increase equal to at least one standard deviation from the country's own history. These criteria lead to the identification of sudden stops listed in table 7A.1.

As also discussed in the text, there remain ambiguities and close calls in identifying a sudden stop. Some, for example, would argue that Brazil experienced a sudden stop in 1999. This would be true if attention was focused only on non-FDI flows. However, FDI inflows partially compensated in that year for non-FDI outflows. Another instance widely viewed as a sudden stop is Russia in 1999, following the events in the final quarter of 1998. Because we have only a short time series on Russia, the measured standard deviation of the financial balance is not very informative. Because these events are plausible candidates for sudden stops, we examined if our results were robust to their being so identified. The first column in table 7A.2 shows that the results remain largely unchanged. The conditioning variables retain their direction of influence and statistical strength. A pegged exchange rate regime is clearly associated with a higher probability of a sudden stop than are more flexible regimes. All the IMF variables are, in this sample, solidly significant.

There is also a concern that sudden stop measured by our procedure may not always reflect the same pressures. Specifically, countries differ in the degree to which they have contact with international financial markets and, hence, in the degree to which they are subject to sharp changes in market sentiment. One criterion for differentiating countries in this dimension is the degree to which they have access to concessional official finance. Pre-

43. Thus, the IMF's then managing director suggested in a February 9, 2006, speech (de Rato 2006) "an instrument carrying relatively high access, available in a single purchase if a capital account crisis occurred, subject to a Fund-supported program being in place and on track." 
Countries in the sample and sudden stop dates

\begin{tabular}{ll}
\hline Country & Year \\
\hline Argentina & 1989 \\
Bangladesh & 1998 \\
Bolovia & 1983 \\
Brazil & 1983 \\
Chile & 1983 \\
Colombia & 1991 \\
Costa Rica & 1982 \\
Czech Republic & 1997 \\
Egypt, Arab Republic of & 2002 \\
Ghana & 2002 \\
Hungary & 1990 \\
Indonesia & 1997 \\
Korea, Republic of & 1986 \\
Malaysia & 1998 \\
Mauritius & 1985 \\
Mexico & 1983 \\
Pakistan & 1998 \\
Peru & 1983 \\
The Philippines & 1998 \\
Poland & 1990 \\
South Africa & 1985 \\
Thailand & 1997 \\
Turkey & 1994 \\
Uruguay & 2002 \\
\hline
\end{tabular}

Note: China, El Salvador, Jordan, Jamaica, and India were included in the sample but they did not have a sudden stop.

sumably, countries that can borrow from the IMF on a concessional basis have less sustained interactions with financial markets than countries that do not so borrow. Four instances of sudden stop are associated with countries that borrowed on concessional terms: Bangladesh (1998), Bolivia (1983), Ghana (2002), and Pakistan (1998). Also, it is possible that the Ghana's sudden stop is misidentified to the extent that capital inflows were recorded as an unusual change in errors and omissions. The second column in table 7A.2 reports the results when these four sudden stops are dropped. The results stay robust. Finally, in column (3), we add Brazil and Russia 1999 and drop the four countries with concessional finance. Once again, our results are confirmed. 


\begin{tabular}{|c|c|c|c|}
\hline & $\begin{array}{c}\text { Added } \\
\text { Brazil and } \\
\text { Russia } 1999\end{array}$ & $\begin{array}{l}\text { Dropped } \\
\text { Bangladesh, } \\
\text { Bolivia, Ghana, } \\
\text { and Pakistan }\end{array}$ & $\begin{array}{c}\text { Added Brazil and Russia } \\
1999 \text { and dropped } \\
\text { Bangladesh, Bolivia, } \\
\text { Ghana, and Pakistan }\end{array}$ \\
\hline High yield spread & $\begin{array}{c}-0.002 \\
{[1.03]}\end{array}$ & $\begin{array}{c}0.0004 \\
{[0.08]}\end{array}$ & $\begin{array}{c}0.0004 \\
{[0.11]}\end{array}$ \\
\hline Change in real oil prices & $\begin{array}{l}-0.001^{* * *} \\
{[3.07]}\end{array}$ & $\begin{array}{l}-0.001^{* * *} \\
{[3.18]}\end{array}$ & $\begin{array}{l}-0.001^{* *} \\
{[2.11]}\end{array}$ \\
\hline GDP growth & $\begin{array}{l}0.005^{* * *} \\
{[2.82]}\end{array}$ & $\begin{array}{l}0.002^{* * *} \\
{[3.35]}\end{array}$ & $\begin{array}{l}0.007 * * * \\
{[3.11]}\end{array}$ \\
\hline Trade balance/GDP & $\begin{array}{r}0.001 \\
{[0.51]}\end{array}$ & $\begin{array}{l}0.0002 \\
{[0.06]}\end{array}$ & $\begin{array}{l}0.0002 \\
{[0.20]}\end{array}$ \\
\hline Debt servicing/Exports & $\begin{array}{l}0.001^{* *} \\
{[2.37]}\end{array}$ & $\begin{array}{l}0.0002^{* *} \\
{[2.21]}\end{array}$ & $\begin{array}{l}0.001^{* *} \\
{[2.05]}\end{array}$ \\
\hline Domestic credit/GDP & $\begin{array}{l}0.001^{* *} \\
{[1.97]}\end{array}$ & $\begin{array}{l}0.0002 * * * \\
{[2.76]}\end{array}$ & $\begin{array}{l}0.001^{* *} \\
{[2.39]}\end{array}$ \\
\hline Change in domestic credit/GDP & $\begin{array}{c}0.001^{*} \\
{[1.71]}\end{array}$ & $\begin{array}{l}0.0002^{* *} \\
{[2.03]}\end{array}$ & $\begin{array}{l}0.001 * * \\
{[1.98]}\end{array}$ \\
\hline Debt/GDP & $\begin{array}{l}0.002^{* * *} \\
{[3.80]}\end{array}$ & $\begin{array}{l}0.001^{* * *} \\
{[4.34]}\end{array}$ & $\begin{array}{l}0.003 * * * \\
{[3.65]}\end{array}$ \\
\hline Change in Debt/GDP & $\begin{array}{l}0.001^{* *} \\
{[2.47]}\end{array}$ & $\begin{array}{l}0.0001^{* *} \\
{[2.50]}\end{array}$ & $\begin{array}{l}0.001^{* *} \\
{[2.51]}\end{array}$ \\
\hline Exchange rate regime: Pegged & $\begin{array}{l}0.145^{* *} \\
{[2.41]}\end{array}$ & $\begin{array}{l}0.188^{* * *} \\
{[2.72]}\end{array}$ & $\begin{array}{l}0.238^{* * *} \\
{[2.60]}\end{array}$ \\
\hline Exchange rate regime: Limited flexibility & $\begin{array}{c}0.03 \\
{[1.41]}\end{array}$ & $\begin{array}{c}-0.004 \\
{[0.22]}\end{array}$ & $\begin{array}{r}0.046 \\
{[1.42]}\end{array}$ \\
\hline Financial mobility & $\begin{array}{c}-0.004 \\
{[1.10]}\end{array}$ & $\begin{array}{c}-0.001^{*} \\
{[1.65]}\end{array}$ & $\begin{array}{r}-0.005 \\
{[1.25]}\end{array}$ \\
\hline Existing IMF program & $\begin{array}{l}-0.010^{* *} \\
{[1.99]}\end{array}$ & $\begin{array}{c}-0.002^{*} \\
{[1.74]}\end{array}$ & $\begin{array}{l}-0.015^{* *} \\
{[2.10]}\end{array}$ \\
\hline New IMF program, instrumented & $\begin{array}{l}-0.071^{* * *} \\
{[2.91]}\end{array}$ & $\begin{array}{l}-0.021^{* * *} \\
{[3.25]}\end{array}$ & $\begin{array}{l}-0.089^{* * *} \\
{[2.61]}\end{array}$ \\
\hline Fundamentals $\cdot$ Program, instrumented & $\begin{array}{l}0.020^{* *} \\
{[1.97]}\end{array}$ & $\begin{array}{l}0.005^{* *} \\
{[2.09]}\end{array}$ & $\begin{array}{l}0.025^{*} \\
{[1.82]}\end{array}$ \\
\hline IMF credit/GDP & $\begin{array}{l}-0.011^{* * *} \\
{[2.58]}\end{array}$ & $\begin{array}{l}-0.003^{* * *} \\
{[4.07]}\end{array}$ & $\begin{array}{l}-0.014^{* * *} \\
{[2.59]}\end{array}$ \\
\hline Country fixed effects & Yes & Yes & Yes \\
\hline Time fixed effects & No & No & No \\
\hline Pseudo $R^{2}$ & 0.38 & 0.48 & 0.48 \\
\hline No. of observations & 217 & 175 & 175 \\
\hline
\end{tabular}

Note: Dependent variable $=$ indicator for first year of sudden stop. Columns reporting probit results present marginal probabilities, based on the STATA command "dprobit." Robust $z$ statistics are presented in brackets. Probability of IMF program estimate as in the first column of table 7.8.

$* * *$ Significant at the 1 percent level.

**Significant at the 5 percent level.

*Significant at the 10 percent level. 


\section{Appendix B}

Table 7B.1

Sources of data and construction of variables

\begin{tabular}{|c|c|}
\hline Variable & Data source and construction \\
\hline Sudden stop & $\begin{array}{l}\text { Identified as described in the text using the annual data on } \\
\text { financial account balance from the BOP database, IMF }\end{array}$ \\
\hline Real growth & Calculated using data from the WEO, IMF \\
\hline Export growth & Calculated using data from the WEO, IMF \\
\hline Domestic credit & IMF's IFS database \\
\hline External debt & World Bank's GDF database \\
\hline Debt servicing & World Bank's GDF database \\
\hline IMF program & $\begin{array}{l}\text { Data from the Policy Development and Review Department of } \\
\text { the IMF }\end{array}$ \\
\hline Precautionary program & $\begin{array}{l}\text { Data from the Policy Development and Review Department of } \\
\text { the IMF }\end{array}$ \\
\hline IMF credit & IMF’s BOP database \\
\hline Financial account balance & IMF's BOP database \\
\hline FDI & IMF's BOP database \\
\hline Portfolio flows & IMF's BOP database \\
\hline Other capital flows & IMF's BOP database \\
\hline Current account balance & IMF's BOP database \\
\hline Capital formation & IMF’s IFS database \\
\hline Financial integration & From Mody and Murshid (2005), updated using data from the IMF \\
\hline Exchange rate regime & From Reinhart and Rogoff (2004) \\
\hline Currency crisis & $\begin{array}{l}\text { From Kaminsky and Reinhart (1999), Berg and Patillo (1999), } \\
\text { Frankel and Rose (1996), Milesi-Ferretti and Razin (1998) and } \\
\text { Frankel and Wei (2004) }\end{array}$ \\
\hline Banking crisis & $\begin{array}{l}\text { From Demirgüç-Kunt and Detragiache (1998) supplemented with } \\
\text { Goldstein, Kaminsky and Reinhart (2000), and Caprio and } \\
\text { Klingebiel (1996) }\end{array}$ \\
\hline U.S. aid & OECD’s DCA database \\
\hline UN voting pattern & From the web site http://home.gwu.edu/ voeten/UNVoting.htm. \\
\hline $\begin{array}{l}\text { U.S. bank's exposure in } \\
\text { emerging market countries }\end{array}$ & Calculated using data from the BIS web site. \\
\hline U.S. growth rate & IMF’s IFS database \\
\hline U.S. treasury bill rate & IMF's IFS database \\
\hline
\end{tabular}

\section{References}

Atoyan, Ruben, and Patrick Conway. 2005. Evaluating the impact of IMF programs: A comparison of matching and instrumental-variable estimators. University of North Carolina at Chapel Hill. Unpublished Manuscript.

Barro, Robert, and Jong-Wha Lee. 2004. IMF programs: Who is chosen and what are the effects? Harvard University and Seoul National University. Unpublished Manuscript.

Berg, Andrew, and Catherine Patillo. 1999. Are currency crises predictable? A test. IMF Staff Papers 46:107-38. Washington, DC: International Monetary Fund. 
Bordo, Michael D., Ashoka Mody, and Nienke Oomes. 2004. Keeping capital flowing: The role of the IMF. NBER Working Paper no. 10834. Cambridge, MA: National Bureau of Economic Research, October.

Broda, Christian, and Eduardo Levy Yeyati. 2003. Dollarization and the lender of last resort. In Dollarization: Debates and policy alternatives, ed. Eduardo Levy Yeyati and Federico Sturzenegger, 101-32. Cambridge, MA: MIT Press.

Calvo, Guillermo A. 2002. Globalization hazard and delayed reform in emerging markets. Economia 2 (Spring): 1-29.

- 2005. Crises in emerging market economies: A global perspective. NBER Working Paper no. 11305. Cambridge, MA: National Bureau of Economic Research, April.

Calvo, Guillermo, Alejandro Izquierdo, and Luis Mejia. 2004. On the empirics of sudden stops: The relevance of balance-sheet effects. NBER Working Paper no. 10520. Cambridge, MA: National Bureau of Economic Research, May.

Caprio, Gerald J., and Daniela Klingebiel. 1996. Bank insolvencies: Cross-country experience. World Bank Policy Research Working Paper no. 1620. Washington, DC: World Bank.

Cavallo, Eduardo, and Jeffrey A. Frankel. 2004. Does openness to trade make countries more vulnerable to sudden stops, or less? Using gravity to establish causality. KSG Working Paper no. RWP04-038. Cambridge, MA: Kennedy School of Government.

Celasun, Oya, and Rodney Ramcharan. 2005. The design of IMF-supported programs: Does the balance sheet of the IMF matter? International Monetary Fund. Unpublished Manuscript.

Chami, Ralph, Sunil Sharma, and Ilhyock Shim. 2004. A model of the IMF as a coinsurance arrangement. IMF Working Paper no. WP/04/219. Washington, DC: International Monetary Fund, November.

Cohen, Daniel, and Richard Portes. 2004. Towards a lender of first resort. CEPR Discussion Paper no. 4615. London, UK: Center for Economic Policy Research, September.

Conway, Patrick. 1994. IMF lending programs: Participation and impact. Journal of Development Economics 45:365-91.

Cordella, Tito, and Eduardo Levy Yeyati. 2004. Country insurance. IMF Staff Papers 52 (special issue): 85-106.

. 2005. A (new) country insurance facility. IMF Working Paper no. WP/05/ 23. Washington, DC: International Monetary Fund, January.

Demirgüç-Kunt, Asli, and Enrica Detragiache. 1998. The determinants of banking crises in developed and developing countries. IMF Staff Papers 45 (1): 81-109. Washington, DC: International Monetary Fund, March.

De Rato, Rodrigo. 2006. The IMF's medium-term strategy: New priorities, new directions. http://www.imf.org.

Dervis, Kemal, and Ceren Ozer. 2005. A better globalization: Legitimacy, government and reform. Washington, DC: Center for Global Development.

Dicks-Mireaux, Louis, Mauro Mecagni, and Susan Schadler. 2000. Evaluating the effect of IMF lending to low-income countries. Journal of Development Economics 61:495-526.

Dreher, Axel. 2005. IMF and economic growth: The effects of programs, loans, and compliance with conditionality. Department of Management, Technology, and Economics ETH Zürich Working Paper. Zürich, Switzerland: Swiss Federal Institute of Technology Zurich, August.

Dreher, Axel, and Nathan Jensen. 2003. Independent actor or agent? An empirical analysis of the impact of U.S. interests on IMF conditions. Yale University Leitner Working Paper no. 2003-4. New Haven, CT: Yale University. 
Edwards, Sebastian. 2005. Capital controls, sudden stops and current account reversals. NBER Working Paper no. 11170. Cambridge, MA: National Bureau of Economic Research, March.

Eichengreen, Barry. 2000. Can the moral hazard caused by IMF bailouts be reduced? Geneva Reports on the World Economy Special Report no. 1. London: Center for Economic Policy Research, September.

Eichengreen, Barry, Kenneth M. Kletzer, and Ashoka Mody. 2006. The IMF in a world of private capital markets. Journal of Banking and Finance 30 (5): 1335-57.

Eichengreen, Barry, and Ashoka Mody. 1998. Interest rates in the north and capital flows to the south: Is there a missing link? International Finance 1:35-58.

Evrensel, Ayse Y. 2002. Effectiveness of IMF-supported stabilization programs in developing countries. Journal of International Money and Finance 21:565-87.

Frankel, Jeffrey A., and Andrew Rose. 1996. Currency crashes in emerging markets: An empirical treatment. Journal of International Economics 41:351-66.

Frankel, Jeffrey A., and Shang-Jin Wei. 2004. Managing macroeconomic crises. NBER Working Paper no. 10907. Cambridge, MA: National Bureau of Economic Research, November.

Goldstein, Morris. 1998. The Asian financial crisis. Washington, DC: Institute for International Economics.

Goldstein, Morris, Graciela Kaminsky, and Carmen M. Reinhart. 2000. Assessing financial vulnerability: An early warning system for emerging markets. Washington, DC: Institute for International Economics.

Goldstein, Morris, and Peter Montiel. 1986. Evaluating fund stabilization programs with multicountry data: Some methodological pitfalls. IMF Staff Papers 33:304-44. Washington, DC: International Monetary Fund.

Gupta, Poonam, Deepak Mishra, and Ratna Sahay. 2003. Output response to currency crises. IMF Working Paper no. WP/03/230. Washington, DC: International Monetary Fund, November.

Hardoy, Ines. 2002. Effect of IMF programmes on growth: A reappraisal using the method of matching. Institute for Social Research Paper 2003:040. Oslo, Norway: Institute for Social Research.

Hutchison, Michael M. 2001. A cure worse than the disease? Currency crises and the output costs of IMF-supported stabilization programs. NBER Working Paper no. 8305. Cambridge, MA: National Bureau of Economic Research, March.

Hutchison, Michael M., and Ilan Noy. 2003. Macroeconomic effects of IMFsponsored programs in Latin America: Output costs, program recidivism and the vicious cycle of failed stabilization. Journal of International Money and Finance 22:991-1014.

Hutchison, Michael M., and Ilan Noy. 2004. Sudden stops and the Mexican wave: Currency crises, capital flow reversals and output loss in emerging markets. University of California at Santa Cruz, Department of Economics. Paper no. 573.

International Monetary Fund. 2004. Are credit booms in emerging markets a concern? World economic outlook (April): 147-66.

Kaminsky, Graciela, and Carmen M. Reinhart. 1999. The twin crises: The causes of banking and balance of payments problems. American Economic Review 93:473-500.

Khan, Mohsin S. 1990. The macroeconomic effects of fund-supported adjustment programs. IMF Staff Papers 37:195-231. Washington, DC: International Monetary Fund.

Killick, Tony. 1995. IMF programmes in developing countries: Design and impact. London, UK: Routledge.

Lane, Timothy, and Steve Phillips. 2000. Does IMF financing result in moral haz- 
ard? IMF Working Paper no. WP/00/168. Washington, DC: International Monetary Fund, October.

Milesi-Ferretti, Gian Maria, and Assaf Razin. 1998. Current account reversals and currency crises: Empirical regularities. IMF Working Paper no. WP/98/89. Washington, DC: International Monetary Fund, June.

Mody, Ashoka, and Antu Murshid. 2005. Growing up with capital flows. Journal of International Economics 65:249-66.

Mody, Ashoka, and Diego Saravia. 2003. Catalyzing capital flows: Do IMF programs work as commitment devices? IMF Working Paper no. WP/03/100. Washington, DC: International Monetary Fund, May.

Mody, Ashoka, and Randall Stone. 2005. The scope of IMF conditionality: How autonomous is the fund? University of Rochester. Unpublished Manuscript.

Mody, Ashoka, and Mark P. Taylor. 2003. Common vulnerabilities. CEPR Discussion Paper no. 3759. London, UK: Center for Economic Policy Research, February.

Oatley, Thomas, and Jason Yackee. 2004. American interests and IMF lending. International Politics 41:415-29.

Ostry, Jonathan D., and Jeromin Zettelmeyer. 2005. Strengthening IMF crisis prevention. IMF Working Paper no. WP/05/206. Washington, DC: International Monetary Fund, November.

Pastor, Manuel. 1987. The effects of IMF programs in the third world: Debate and evidence from Latin America. World Development 15:249-62.

Przeworski, Adam, and James Raymond Vreeland. 2000. The effect of IMF programs on economic growth. Journal of Development Economics 62:385-421.

Reinhart, Carmen, and Kenneth Rogoff. 2004. The modern history of exchange rate arrangements: A reinterpretation. Quarterly Journal of Economics 119:1-48.

Sarno, Lucio, and Mark P. Taylor. 1999. Hot money, accounting labels and the permanence of capital flows to developing countries: An empirical investigation. Journal of Development Economics 59 (2): 337-64.

Truman, Edwin. 2005. International Monetary Fund reform: An overview of the issues. Institute for International Economics . Unpublished Manuscript.

\section{Comment Ilan Goldfajn}

This is a very nice and important paper that the authors have written. It asks the relevant question whether the IMF helps reduce the incidence and impact of sudden stops. Sudden stops are abrupt declines in net capital inflows, leading to balance of payment crises and output losses. Given their importance and high incidence, it is quite surprising that this question was not analyzed earlier.

The main results of the paper could be summarized as follows:

I. Economies that have IMF programs in place (existing or recently negotiated) reduce their probability of suffering a sudden stop.

Ilan Goldfajn is a professor of economics at the Pontifical Catholic University of Rio de Janeiro (PUC-Rio) and a director of the Casa das Garças Institute for Economic Policy Studies (IEPE/CdG). 
a. IMF programs work best for countries with stronger fundamentals.

b. Larger IMF programs reduce the incidence of sudden stops.

II. IMF programs do not attenuate the impact of sudden stops on GDP growth.

Let's concentrate on the first result. Do IMF programs reduce the incidence of sudden stops? The paper provides a clear yes answer to the question with convincing evidence: The results hold notwithstanding that there is a reverse causality (sudden stops generate IMF programs) that tends to bias the coefficients to zero. When using the U.S. "friendship" instrument (proxied by U.S. aid to the country and UN voting with U.S. record, borrowed from Barro and Lee), as expected, the coefficients become stronger.

This result is a very important policy issue since it provides evidence in favor of the insurance role of the IMF. The insurance role is the provision of emergency financial assistance that reassures investors of the country's ability to pay its liabilities and avoid costly defaults. This insurance result gives support to those who would like to strengthen the IMF role in providing facilities with quick disbursements in order to prevent and reduce the incidence of sudden stops.

Since larger IMF programs (and not only the existence of a program) and stronger fundamentals also help reduce the incidence of sudden stops, the results call for facilities with larger disbursements that are conditional on economies that follow strong economic policies. This would mimic the lender-of-last-resort role of central banks: quick, large, automatic facilities for prequalified countries.

The results of the paper cannot distinguish completely the insurance role of IMF programs from other roles of the IMF programs as the signalling effect: the positive signal that an IMF program in place gives investors regarding the willingness of countries to adopt strong measures and also to pay the existing liabilities.

It is important to note that the insurance role of the IMF is broader than what the regressions in the paper can capture. The sheer IMF existence (and potential lender of last resort role) should reduce the incidence of sudden stops, even if there are no programs in place in a specific country. The lender of last resort role affects expectations even before IMF programs are designed and take place. It is clear that the insurance role of the IMF is even stronger than what the results of the paper suggest.

One could even test this broader insurance role using the data in the paper. One could regress the U.S. support proxy on sudden stops. A positive coefficient would provide a first pass evidence for this broader insurance role (provided one believes that U.S. support increases the probability of receiving an IMF program ceteris paribus).

Given the importance of the insurance role, one should take seriously into consideration the moral hazard issue: do countries adopt less strin- 
gent policies because of the lender of last resort role of the IMF? The paper does not address this issue, but it is clearly an important topic for discussion.

In this regard, any IMF facility for insurance purposes should target countries with preexisting conditions (good policies, etc.). The recent failed IMF's Credit Contingent Line (CCL) is an important warning for practical obstacles: the facility failed not only because of the exit problem (any IMF expelled country is a crisis-prone one) but also because of its negative signalling (if a country applies, it must believe there is a problem in the making. It is the Groucho Marx paradox).

The second result of the paper is more negative for the role of the IMF. Do IMF programs reduce the impact of sudden stop on growth? Although figure 7.4 in the paper (and my prior-more reserves to intervene and avoid the need for sharp current account reversals) suggests this is the case, the empirical results in the paper do not back this proposition.

In sum, the paper asks very important questions and provides useful preliminary evidence. Further work on the impact of IMF programs on the costs of sudden stops is needed. 